\title{
Episodic crustal anatexis and the formation of Paiku composite leucogranitic pluton in the Malashan Gneiss Dome, Southern Tibet
}

\author{
GAO LiE $^{1 *}$, ZENG LingSen $^{1}$, HOU KeJun ${ }^{2}$, GUO ChunLi ${ }^{2}$, TANG SuoHan ${ }^{1}$, XIE KeJia ${ }^{3}$, \\ HU GuYue ${ }^{2} \&$ WANG Li ${ }^{1}$ \\ ${ }^{1}$ State Key Laboratory of Continental Tectonics and Dynamics, Institute of Geology, Chinese Academy of Geological Sciences, \\ Beijing 100037, China; \\ ${ }^{2}$ Institute of Mineral Resources, Chinese Academy of Geological Sciences, Beijing 100037, China; \\ ${ }^{3}$ Non-Ferrous Mineral Exploration Engineering Research Center of Henan Province, Zhengzhou 450016, China
}

Received December 18, 2012; accepted February 26, 2013; published online April 16, 2013

\begin{abstract}
The Paiku composite leucogranitic pluton in the Malashan gneiss dome within the Tethyan Himalaya consists of tourmaline leucogranite, two-mica granite and garnet-bearing leucogranite. Zircon U-Pb dating yields that (1) tourmaline leucogranite formed at $28.2 \pm 0.5 \mathrm{Ma}$ and its source rock experienced simultaneous metamorphism and anatexis at 33.6 $\pm 0.6 \mathrm{Ma}$; (2) two-mica granite formed at $19.8 \pm 0.5 \mathrm{Ma}$; (3) both types of leucogranite contain inherited zircon grains with an age peak at $\sim 480 \mathrm{Ma}$. These leucogranites show distinct geochemistry in major and trace elements as well as in Sr-Nd-Hf isotope compositions. As compared to the two-mica granites, the tourmaline ones have higher initial $\mathrm{Sr}$ and zircon Hf isotope compositions, indicating that they were derived from different source rocks combined with different melting reactions. Combined with available literature data, it is suggested that anatexis at $\sim 35 \mathrm{Ma}$ along the Himalayan orogenic belt might have triggered the initial movement of the Southern Tibetan Detachment System (STDS), and led to the tectonic transition from compressive shortening to extension. Such a tectonic transition could be a dominant factor that initiates large scale decompressional melting of fertile high-grade metapelites along the Himalayan orogenic belt. Crustal anatexis at $\sim 28 \mathrm{Ma}$ and $\sim 20 \mathrm{Ma}$ represent large-scale melting reactions associated with the movement of the STDS.
\end{abstract}

Himalayan orogenic belt, Northern Himalayan Gneiss Domes, leucogranite, crustal anatexis, tectonic transition

Citation: Gao L E, Zeng L S, Hou K J, et al. Episodic crustal anatexis and the formation of Paiku composite leucogranitic pluton in the Malashan Gneiss Dome, Southern Tibet. Chin Sci Bull, 2013, 58: 3546-3563, doi: 10.1007/s11434-013-5792-4

Cenozoic leucogranites within the Himalayan collisional orogenic belt is one of the type examples of S-type granite worldwide. Knowledge of their geochemical nature and timing of formation could not only potentially promote our understanding of the melting behaviors of deep crustal rocks during collisional orogenic processes, but also provide key geochemical and temporal constraints on the tectonic evolution of the Himalayan orogenic belt. Earlier studies on these Cenozoic granites have demonstrated that most of them formed at 27-10 Ma [1-4] and were derived from in situ partial melting of high-grade metapelites [3,5,6]. Experi-

*Corresponding author (email: liegao09@gmail.com) mental results have demonstrated that partial melting of Formation-I kyanite-bearing metapelite indeed can produce melts with elemental and isotopic compositions resembling the Himalayan Cenozoic leucogranites [6,7], however, increasing number of updated studies have documented that episodic anatexis occurred in the Northern Himalayan Gneiss Domes (NHGD) as well as in the High Himalayan Crystalline Sequence (HHCS) since the continental collision between India and Eurasia. These anatectic episodes include (1) dehydration melting of a source consisting dominantly of amphibolite with subordinate pelitic gneiss at thickened crustal conditions [8-14]. These melting events are represented by older than 35 Ma peraluminous granitoids with 
relatively high $\mathrm{Na} / \mathrm{K}$ and $\mathrm{Sr} / \mathrm{Y}$ ratios; (2) fluid-present melting of metapelite since $\sim 38 \mathrm{Ma}$ to produce granitic melts with high $\mathrm{CaO}$ and $\mathrm{Sr}$ contents and low $\mathrm{Rb} / \mathrm{Sr}$ ratios [15-18]; and (3) late Eocene to early Oligocene anatexis recorded in syn-collision leucogranites and migmatites in the Gyirong area and the Mabja Gneiss Dome [19-21]. A large number of studies have demonstrated that metapelites are fertile and could undergo progressive partial melting with variations in temperature, pressure, and water content, which leads to the formation of granites with different geochemical characteristics in major and trace element as well as in isotope (e.g. Sr, Nd) geochemistry [4,6,7,16,18,22,23]. Therefore, these granites provide an important probe to investigate how the middle-lower crustal rocks respond to the tectonic evolution of orogenic belts. Data summarized above indicate that partial melting in the Himalayan orogenic belt could be traced back to the middle Eocene and sources and mechanisms of anatexis are more complex than previous thought, therefore, more studies are required to determine the geochemical nature and the timing of partial melting processes along the Himalayan orogen in order to refine our understanding on the deep processes in large orogenic belts and draw broader tectonic implications.

Limited studies have been performed on the Malashan Gneiss Dome (MGD) in the west of NHGD. Aoya et al. [24] and Kawakami et al. [25] had investigated the nature and sequence of metamorphism and deformation in the wallrocks of Malashan granites and shown that the wall-rocks had experienced contact metamorphism due to the intrusion of the Malashan granite. Zircon U-Pb and mica ${ }^{40} \mathrm{Ar} /{ }^{39} \mathrm{Ar}$ dating results reported by Aoya et al. [26], Kawakami et al. [25] and Zhang et al. [21] suggested that the Malashan granite crystallized over a long time span ( 10 myr), which could be due to mixing ages from domains straddling across different growth zonings. To the south of the Malashan granite, recent field investigations found that the Paiku leucogranite is a composite pluton rather than a single one $[25,26]$. This pluton consists of tourmaline leucogranite, two-mica leucogranite, and garnet-bearing granite. In order to narrow down the formation age and characterize the mineral and geochemical composition of this leucogranitic pluton, we have sampled along traversals across this pluton as shown in Figure 1(b) and conducted bulk-rock major and trace element and radiogenic isotope ( $\mathrm{Sr}$ and $\mathrm{Nd}$ ), as well as
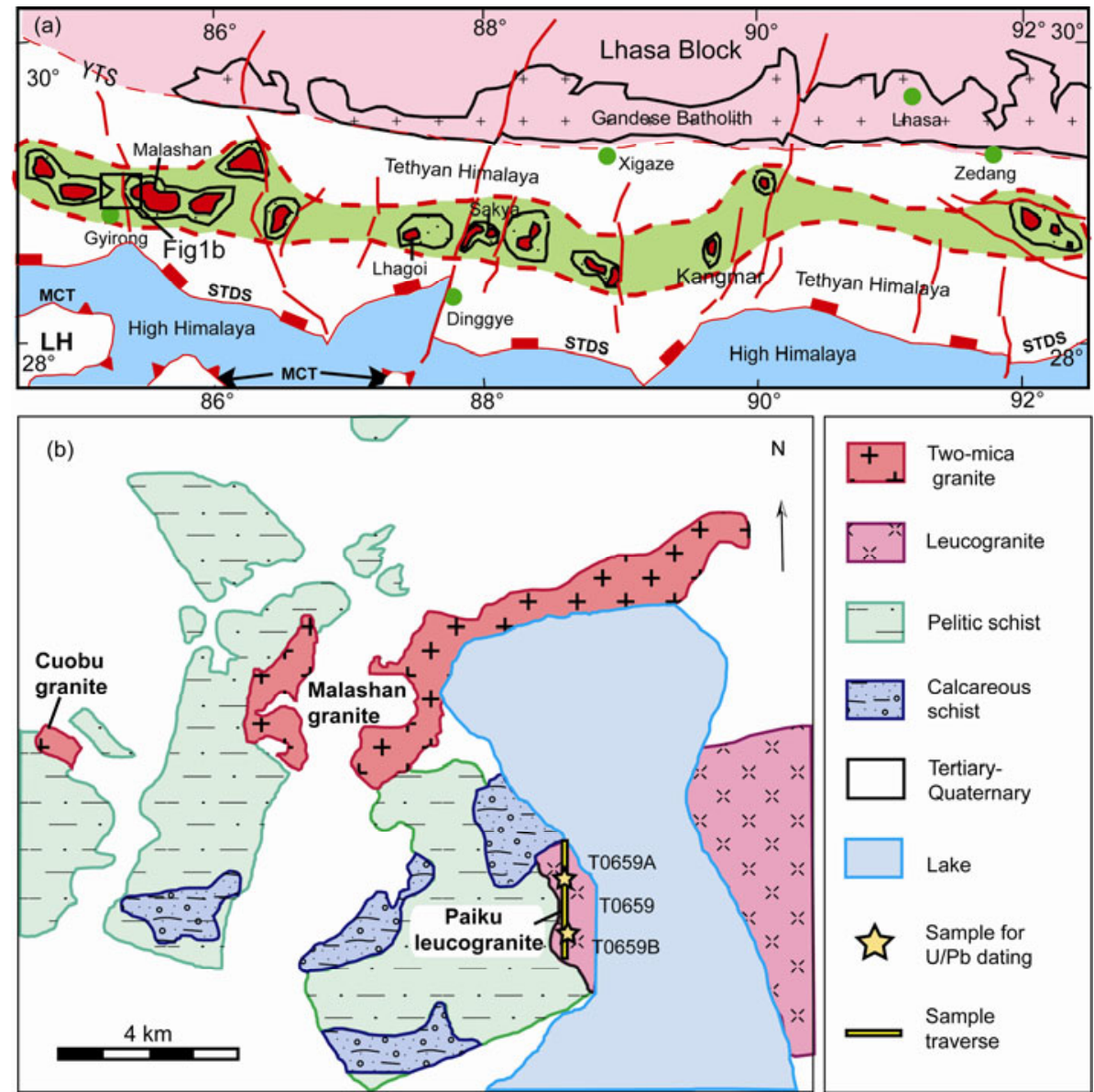

Figure 1 (a) Simplified geologic map of the Himalayan orogenic belt, southern Tibet (after Zeng et al. [12]); (b) simplified geological map of the Malashan Gneiss Dome (after Aoya et al. [24]). YTS, Yarlung-Tsangpo suture; STDS, Southern Tibet Detachment System; MCT, Main Center Thrust; MBT, Main Boundary Thrust; LH, Lower Himalayan Crystalline Sequence. 
LA-MC-ICP-MS zircon U/Pb and $\mathrm{Hf}$ isotope analyses on tourmaline- and two-mica granites.

\section{Geological setting and sample descriptions}

Leucogranites in the Himalayan orogen are distributed along two sub-parallel belts, HHCS and NHGD, which are separated by the Southern Tibetan Detachment System (STDS) (Figure 1(a)). Granites, migmatites, and high-grade metamorphic rocks are important components within these two belts and record distinct types of metamorphism and partial melting reactions of middle-lower crustal materials in response to the tectonic evolution of the Himalayan orogen $[1,4,8,13,14,16,26-29]$. NHGD within the Tethyan Himalaya consists of a series of semi-continuous oval shape gneiss dome. These domes share similar features and consist of highgrade metamorphic rocks and intruded granites in the core and low grade metamorphic or unmetamorphosed sedimentary toward the margin. All these rock units are separated by ductile detachment fault. Except for the Kangmar Dome, all granites within the NHGD are younger than $44 \mathrm{Ma}$ $[3,4,8,12,13,16,19,26,30]$; whereas the granites within the HHCS formed at 37-10 Ma and are characterized by apparently lower melt temperature [3].

Granites in the Malashan Gneiss Dome include the Cuobu two-mica granite (TMG), Malashan two-mica granite (TMG) and Paiku leucogranite (Figure 1(b)). These granites intruded into pelitic and calcareous schist mapped as Jurassic and Cretaceous in age [31]. Presence of andalusite and skarn formation in the metasediments within the proximity of these granites indicates relatively intensive contact metamorphism in the sedimentary wall-rocks induced by the emplacement of granitic plutons [24,25]. The Paiku composite leucogranite pluton consists of tourmaline leucograntie, two-mica granite and garnet-bearing leucogranite. Detailed field investigations on the cross-cutting relationship between these leucogranites indicate that the pelitic sediments were first intruded by the tourmaline leucogranites, followed by the intrusion of the Paiku TMG, and finally the Malashan TMG. Major features in the Malashan dome include: (1) the Malashan TMG experienced strong deformation, but others not [24,26,32]; (2) presence of Barroviantype metamorphism with grade increasing toward the granite core [25]; (3) development of two major episodes of ductile deformation represented by earlier top-to-the south D1 and later top-to-the north D2 fabric, respectively. The intensity of D2 fabric increased toward the granite contact; (4) roughly north-south D2 flow direction indicated by the D2 stretching lineation; and (5) no sillimanite or migmatite found in the metasedimentary wall-rocks implies relatively lower metamorphic grade than the other gneiss domes [24,26]. The least deformed Cuobu granite has strikingly similar bulk chemical compositions to those of the Malashan granite, but is apparently different from the Paiku leucogranite [26].
Sensitive high-resolution ion microprobe zircon $\mathrm{U}-\mathrm{Pb}$ dating yielded that the Cuobu TMG formed at 26.0-13.7 Ma [26], Malashan TMG at 30.2-17.2 Ma [21,26]. ${ }^{40} \mathrm{Ar}-{ }^{39} \mathrm{Ar}$ dating on muscovite and biotite yielded similar cooling ages of 17.6-15.3 Ma for the Cuobu and Malashan TMG, respectively [21,26]. The Paiku leucogranite formed at 22.2-16.2 Ma, and ${ }^{40} \mathrm{Ar}-{ }^{39} \mathrm{Ar}$ cooling age is $15.9 \mathrm{Ma}$ [25].

Leucogranites within the Paiku pluton contain largely similar mineral assemblage and textures with variations in relative proportion in muscovite. All three types of leucogranite consist of quartz, plagioclase, muscovite, and accessory phases of zircon, apatite and monazite. The tourmaline leucogranite contains more muscovite ( 20\%) than others $(<15 \%)$. The tourmaline leucogranites contain abundant (up to $10 \%$ ) large, euhedral, and compositionally zoned tourmaline grains (Figure 2(b)), in contrast, two-mica granite contains 5\%-10\% biotite (Figure 2(c)) and garnet-bearing leucogranite contains up to $2 \%$ large and subhedral garnet grains (Figure 2(d)). Sample T0659-A is a representative tourmaline leucogranite and has a similar mineral assemblage and microstructure to sample T0659-1 to T0659-6, whereas T0659-B is two-mica granite similar to sample T0659-11 to T0659-14.

\section{Analytical methods}

\subsection{LA-MC-ICP-MS zircon U-Pb dating}

Zircons were separated from representative sample T0659A and sample T0659-B from Paiku Cuo (Figure 1(b)) by using standard heavy-liquid and magnetic techniques, and then handpicked under a binocular microscope. The selected grains were embedded in $25 \mathrm{~mm}$ epoxy discs and grounded to approximately half of their thickness. The internal growth structure of zircon grains was revealed by cathodoluminescence (CL) and BSE imaging technique. CL images were obtained at the Beijing SHRIMP Centre, Chinese Academy of Geological Sciences (CAGS). BSE images were obtained with a JSM-5610LV scanning microscope at the Institute of geology, CAGS.

The zircons were analyzed for $\mathrm{U}, \mathrm{Th}$, and $\mathrm{Pb}$ using LAMC-ICP-MS at Key Laboratory of Metallogeny and Mineral Assessment, Institute of Mineral Resources, CAGS, following the procedures described by Hou et al. [33]. Spot sizes were $\sim 25 \mu \mathrm{m}$ and data were calibrated by the M127 reference zircon (U: 923 ppm; Th: 439 ppm; Th/U: 0.475) [34]. The standard zircon was analyzed first and then after every five unknowns. The GJ-1 zircon with an age of 599.8 \pm 1.7 Ma $(2 \sigma)[35]$ was used as a standard. Data process was carried out using the ICPMSDataCal programs [36], and for the ${ }^{206} \mathrm{~Pb} /{ }^{204} \mathrm{~Pb}$ values of most analysis spots larger than 1000 , measured ${ }^{204} \mathrm{~Pb}$ was not applied for the common lead correction, thus those analysis with unusual high ${ }^{204} \mathrm{~Pb}$ are deleted due to the influence of common lead in inclusions. The analytical data are summarized in Table 1, and graphically 

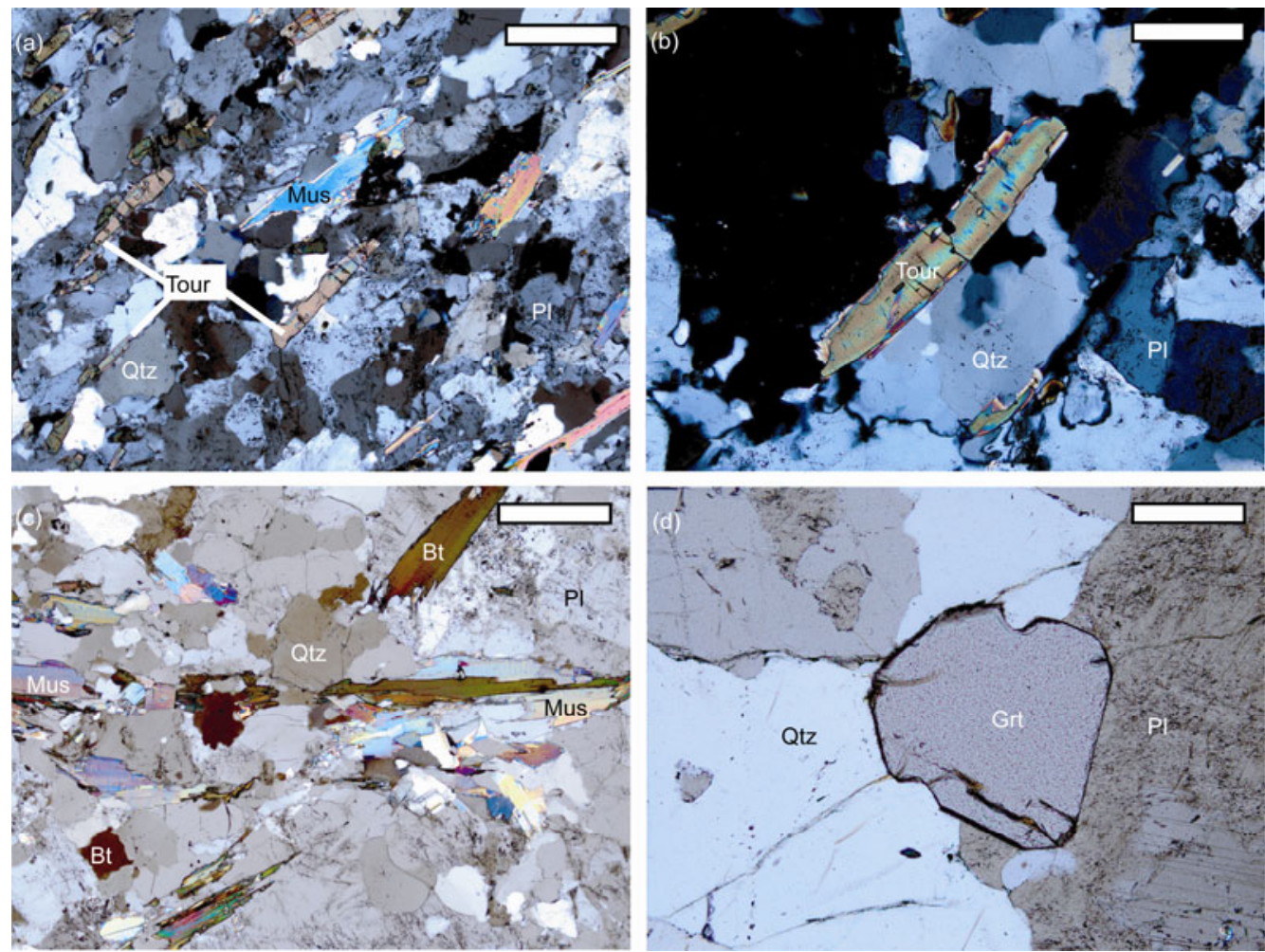

Figure 2 Photomicrographs showing the texture and mineral assemblage of three types of leucogranite in the Paiku area. (a) and (b) tourmaline leucogranite T0659-03 consists of quartz, plagioclase, muscovite and euhedral compositionally zoned tourmaline; (c) two-mica granite T0659-11 consists of quartz, plagioclase, muscovite and biotite; (d) garnet-bearing leucogranite T0659-09 consists of quartz, plagioclase, muscovite and garnet. Except for (a) and (c) with a 500- $\mu \mathrm{m}$-long scale bar, the others are $250 \mu \mathrm{m}$ long. Bt, biotite; Grt, garnet; Mus, muscovite; Pl, plagioclase; Qtz, quartz; Tour, tourmaline.

presented on concordia diagrams with $1 \sigma$ error. The ages are weighted means with $2 \sigma$ errors calculated using Isoplot at $95 \%$ confidence levels [37].

\subsection{Zircon Hf isotope analysis}

Zircon Hf isotope analysis was carried out in-situ using a Newwave UP213 laser-ablation microprobe, attached to a Neptune multi-collector ICP-MS at Institute of Mineral Resources, CAGS, Beijing. Instrumental conditions and data acquisition were comprehensively described by Hou et al. [38]. A stationary spot was used for the present analyses, with a beam diameter of $40 \mu \mathrm{m}$. The analyses were performed on the same zircon domains where the U-Pb dating had been conducted or on the zircons with similar texture. Helium was used as carrier gas to transport the ablated sample from the laser-ablation cell to the ICP-MS torch via a mixing chamber mixed with Argon. In order to correct the isobaric interferences of ${ }^{176} \mathrm{Lu}$ and ${ }^{176} \mathrm{Yb}$ on ${ }^{176} \mathrm{Hf},{ }^{176} \mathrm{Lu} /$ ${ }^{175} \mathrm{Lu}=0.02658$ and ${ }^{176} \mathrm{Yb} /{ }^{173} \mathrm{Yb}=0.796218$ ratios were applied [39]. For instrumental mass bias correction, $\mathrm{Yb}$ isotope ratios were normalized to ${ }^{172} \mathrm{Yb} /{ }^{173} \mathrm{Yb}$ of 1.35274 [39] and $\mathrm{Hf}$ isotope ratios to ${ }^{179} \mathrm{Hf} /{ }^{177} \mathrm{Hf}$ of 0.7325 using an exponential law. The mass bias behavior of $\mathrm{Lu}$ was assumed to follow that of $\mathrm{Yb}$, mass bias correction protocols details was described as Wu et al. [40] and Hou et al. [38]. Zircon GJ-1 and Plesovice were used as the reference standards during our routine analyses, with a weighted mean ${ }^{176} \mathrm{Hf} /{ }^{177} \mathrm{Hf}$ ratio of $0.282007 \pm 0.000007(2 \sigma, n=36)$ and $0.282476 \pm 0.000004$ $(2 \sigma, n=27)$, respectively. It is not distinguishable from a weighted mean ${ }^{176} \mathrm{Hf} /{ }^{177} \mathrm{Hf}$ ratio of $0.282000 \pm 0.000005(2 \sigma)$ and $0.282482 \pm 0.000008(2 \sigma)$ using a solution analysis method by Morel et al. [41] and Sláma et al. [42], respectively. To calculate the initial $\mathrm{Hf}$ isotope compositions, age of $\sim 28 \mathrm{Ma}$ and $\sim 20 \mathrm{Ma}$ were assigned for the Paiku tourmaline leucogranites and two-mica granites based on their $\mathrm{U} / \mathrm{Pb}$ zircon age, respectively. Analytical results are listed in Table 2.

\subsection{Major and trace element analysis}

Whole rock powders for 12 whole-rock samples were prepared by using a tungsten carbide shatter box. Bulk rock major, trace and rare earth element concentrations were obtained by X-ray fluorescence (XRF) and inductively coupled plasma mass spectrometry (ICP-MS) at the National Research Center for Geoanalysis, CAGS, Beijing. Major elements were analyzed by the XRF method with analytical uncertainties $<5 \%$. Trace and rare earth elements were analyzed by ICPMS. REE were separated using cation-exchange techniques. Analytical uncertainties are $10 \%$ for elements with abundances $<10 \mathrm{ppm}$, and around 5\% for those $>10 \mathrm{ppm}$. Analytical results are listed in Table 3. 


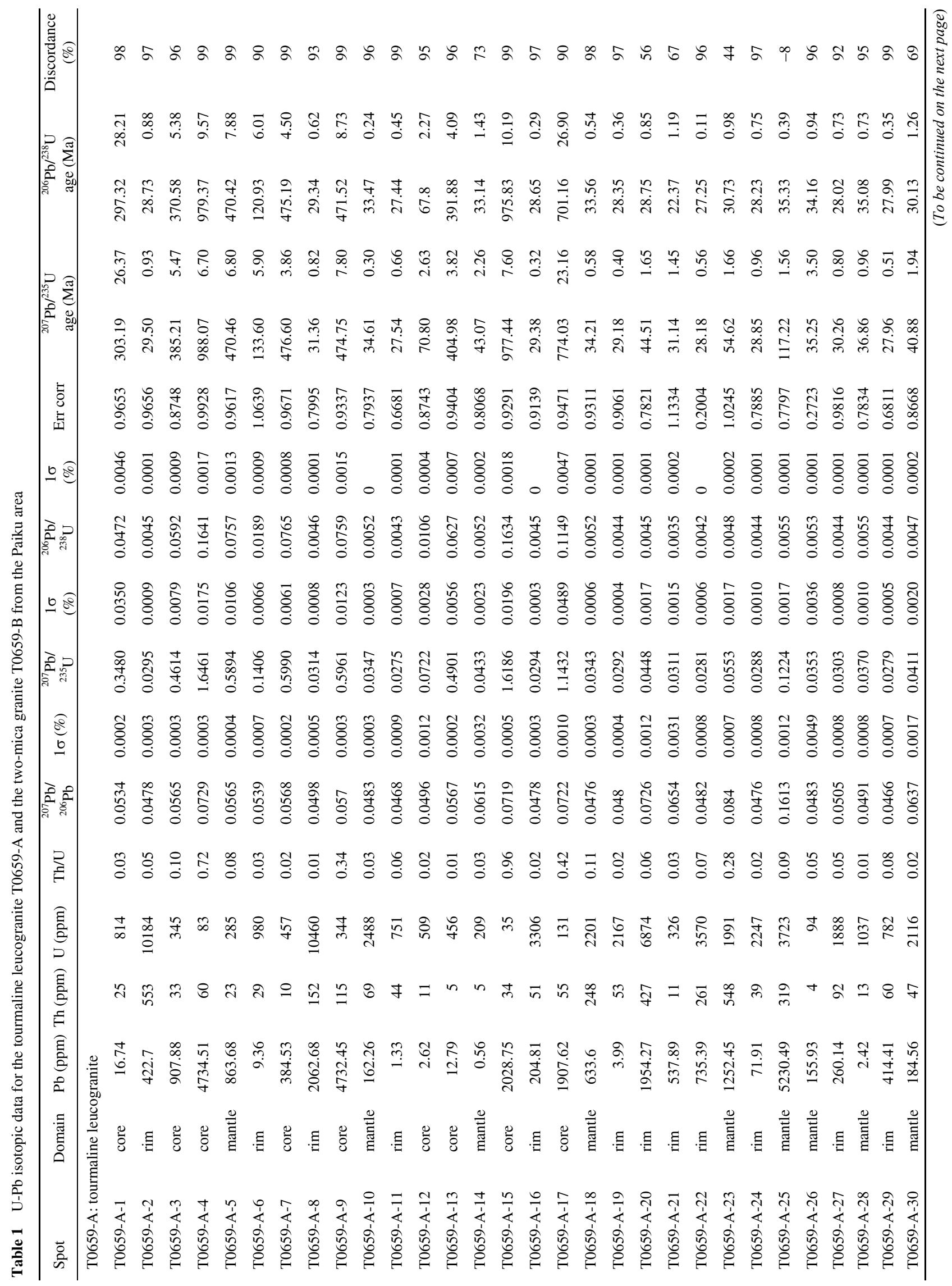




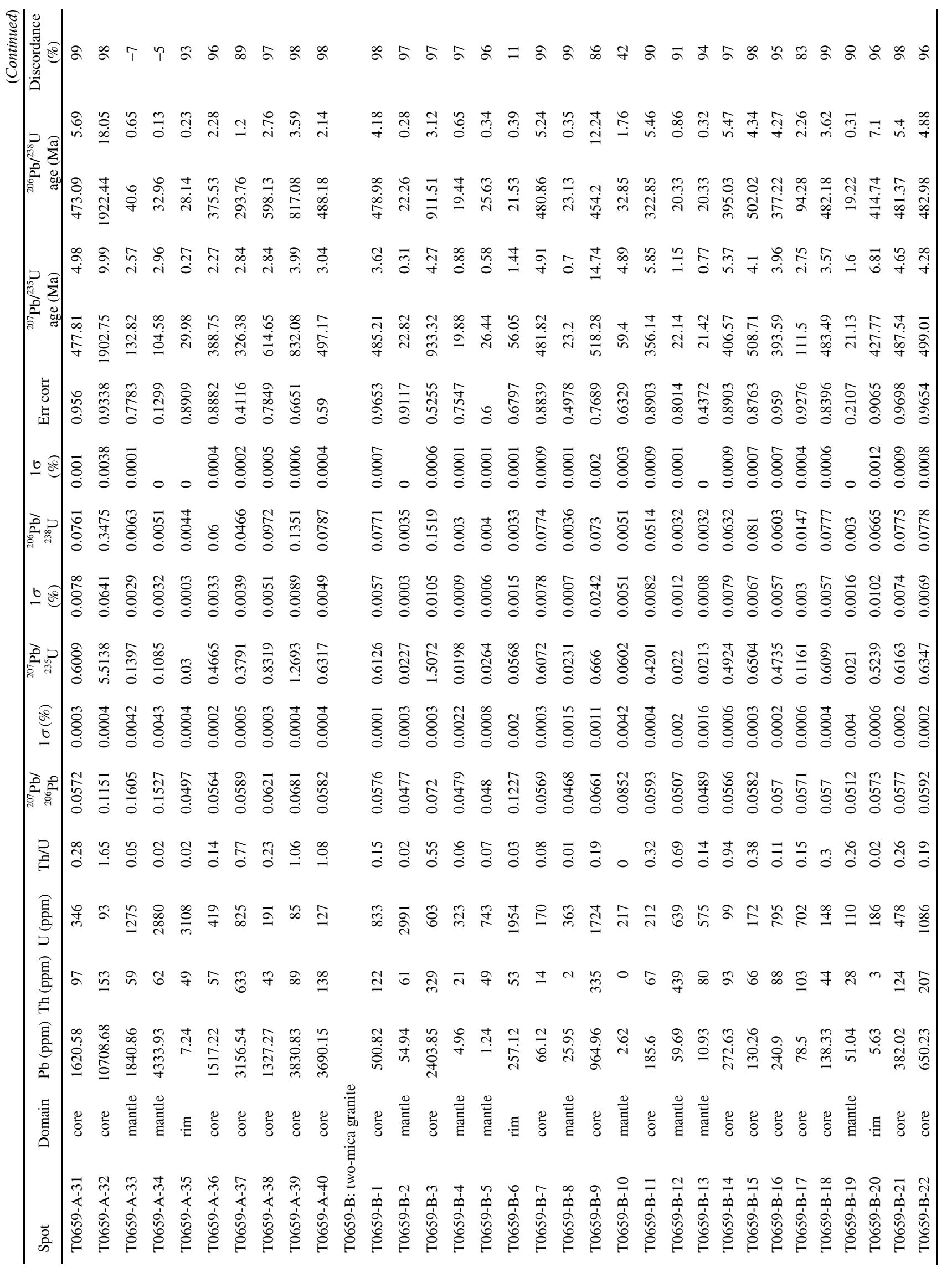




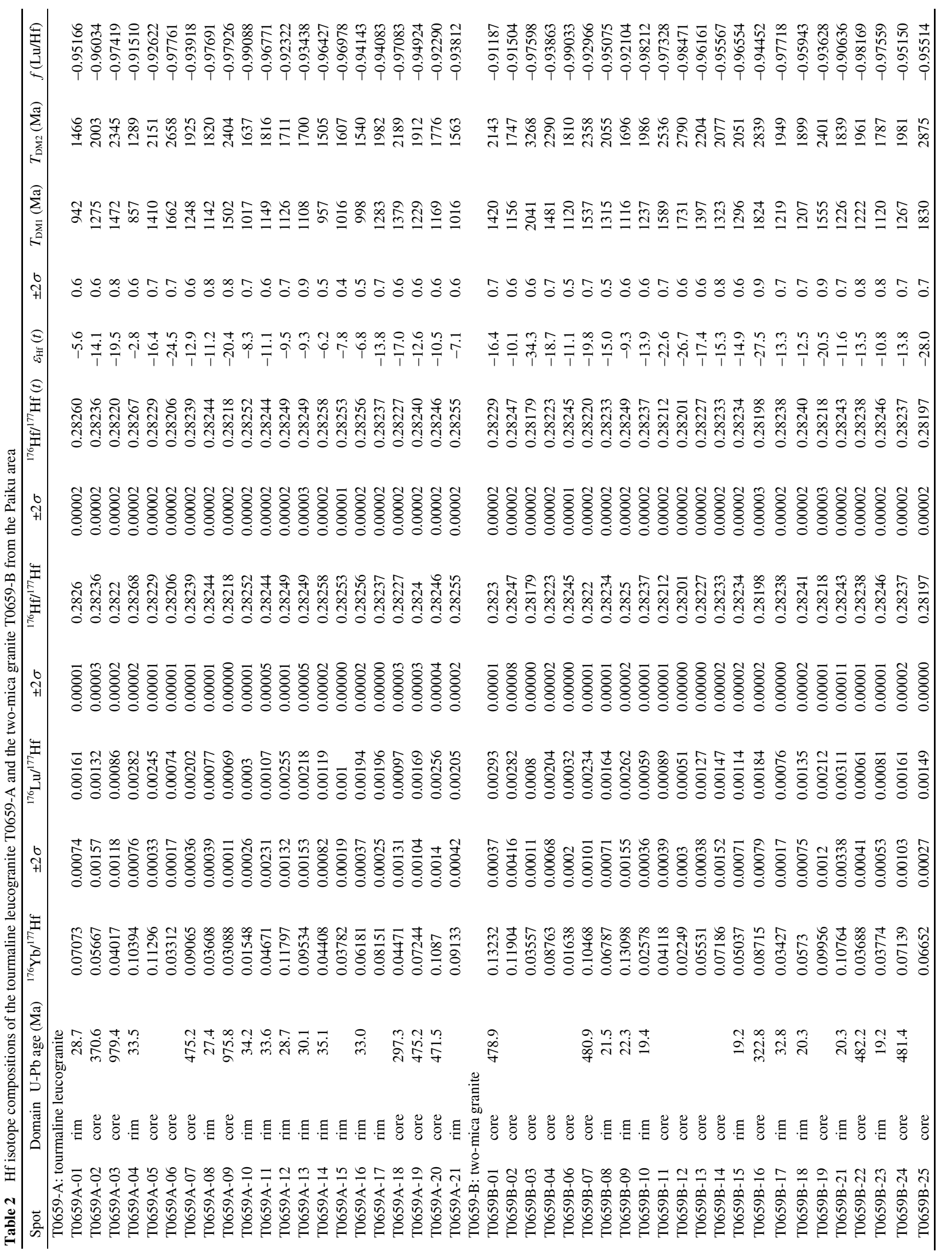




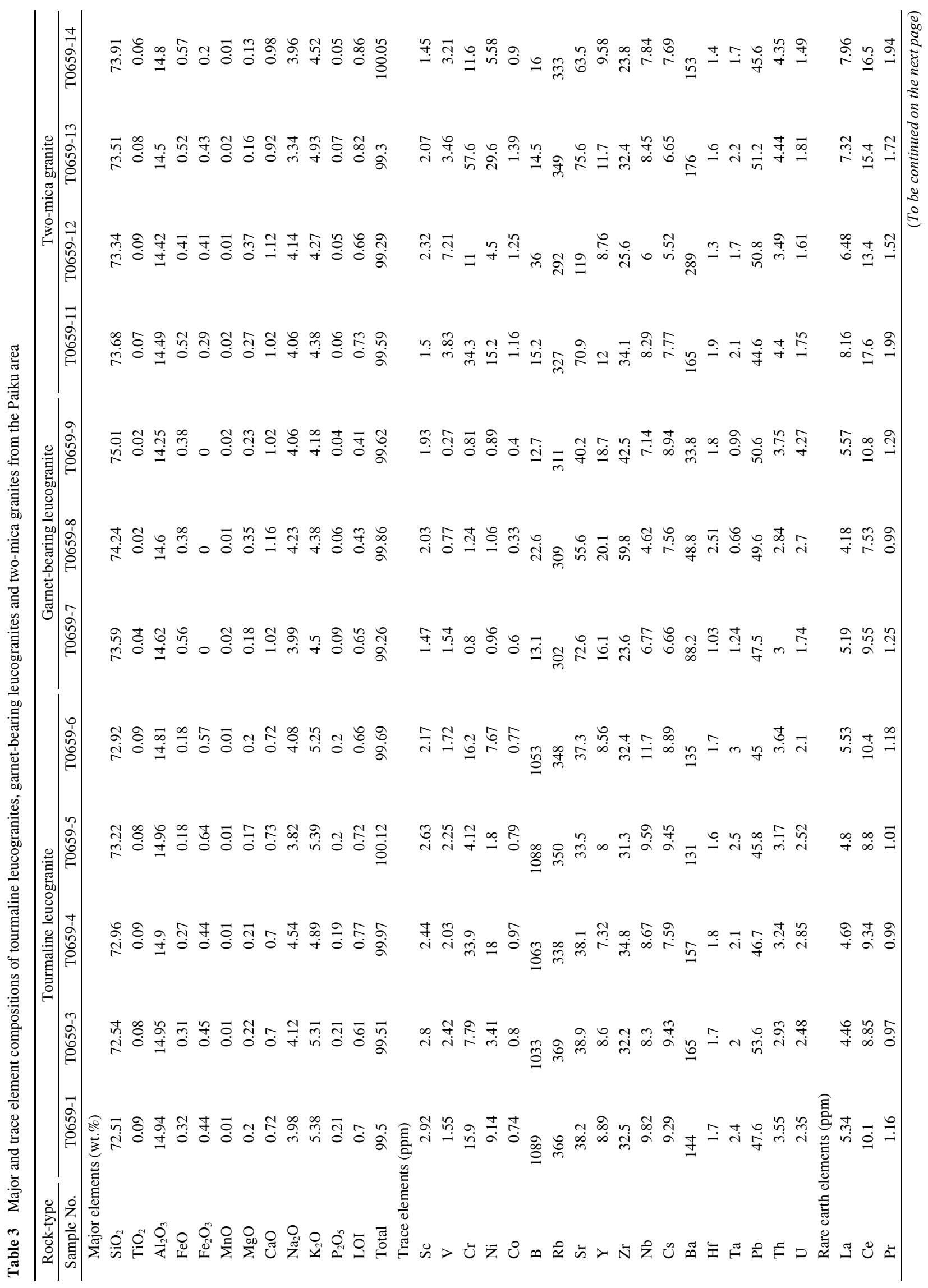




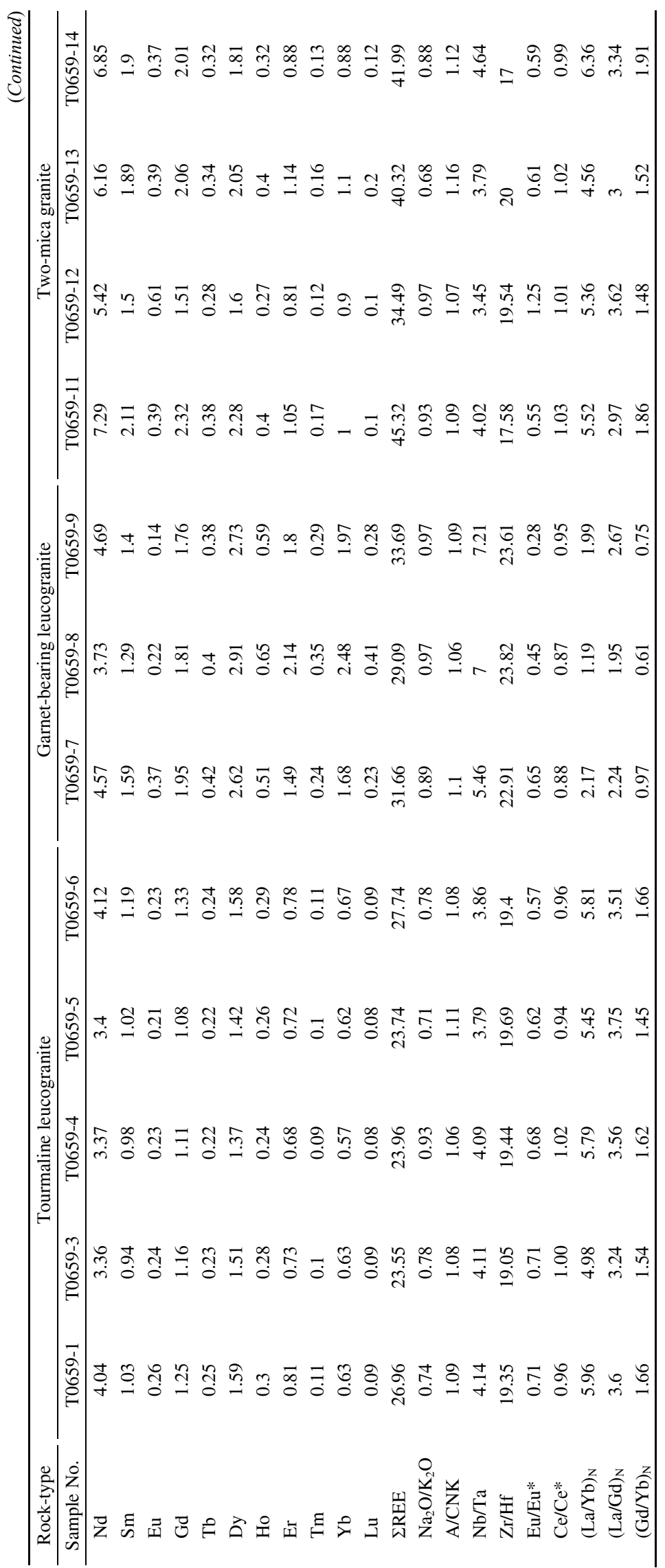

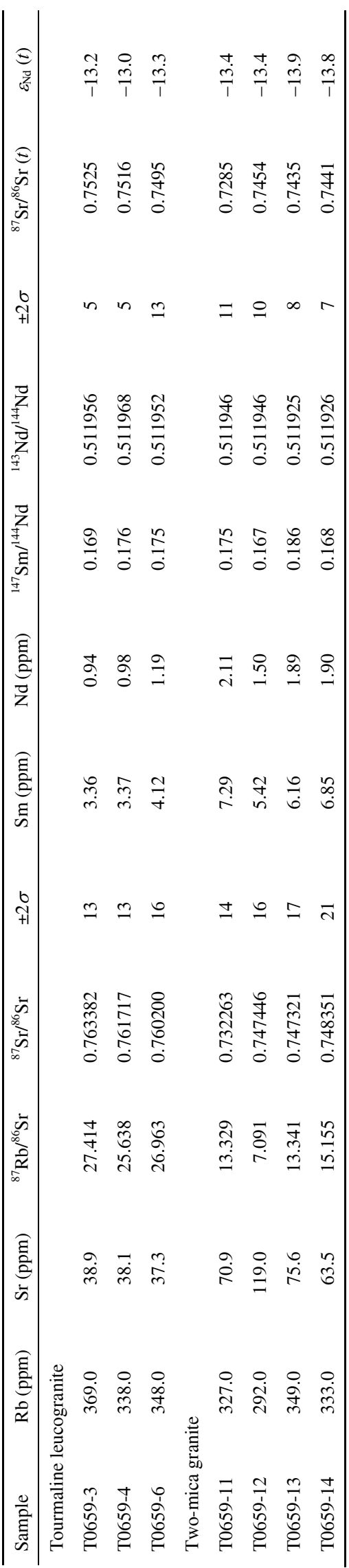




\subsection{Sr and Nd isotope analysis}

$\mathrm{Rb}-\mathrm{Sr}$ and $\mathrm{Sm}-\mathrm{Nd}$ isotope analyses were performed in the Laboratory for Isotope Analysis, Institute of Geology, CAGS. The $\mathrm{Sr}$ isotope compositions and concentrations of $\mathrm{Rb}, \mathrm{Sr}$, $\mathrm{Sm}$, and $\mathrm{Nd}$ were measured by isotope dilution on a Finnigan MAT-262 mass spectrometer. Nd isotope compositions were acquired by a $\mathrm{Nu}$ Plasam HR MC-ICP-MS (Nu Instruments). The $\mathrm{Nd}$ and $\mathrm{Sr}$ measurements were corrected for mass fractionation by normalization to ${ }^{146} \mathrm{Nd} /{ }^{142} \mathrm{Nd}=0.7219$, and ${ }^{86} \mathrm{Sr} /{ }^{88} \mathrm{Sr}=0.1194$. External precisions during this period of measurement for $\mathrm{Sr}$ and $\mathrm{Nd}$ isotopic compositions are $\pm 0.000010(n=18)$ and $\pm 0.000011(n=18)$, respectively. ${ }^{87} \mathrm{Sr} /$ ${ }^{86} \mathrm{Sr}$ for the NBS987 standard is $0.710247 \pm 12(2 \sigma)$ and ${ }^{143} \mathrm{Nd} /{ }^{144} \mathrm{Nd}$ for JMC Nd standard is $0.511127 \pm 12(2 \sigma)$. At $\sim 28 \mathrm{Ma}$ and $\sim 20 \mathrm{Ma}$ were assigned to calculate the initial $\mathrm{Sr}$ and $\mathrm{Nd}$ isotope compositions for the Paiku tourmaline leucogranites and two-mica granites based on their $\mathrm{U} / \mathrm{Pb}$ zircon age. Analytical results are listed in Table 4.

\section{Date and results}

\subsection{The U/Pb zircon age of leucogranites}

Sample T0659-A is a representative sample of tourmaline leucogranite that consists of quartz, plagioclase, muscovite, tourmaline, and accessory zircon, apatite, and monazite. Most of zircon grains in this sample are euhedral to subhedral, long prismatic, 100-150 $\mu \mathrm{m}$ long with aspect ratios commonly of 2.5. These zircons show a similar core-mantle-rim texture both in CL and in BSE images (Figure 3(a)-(d)). The cores are either homogeneous (Figure 3(a), (b)) or weak oscillatory zoning (Figure 3(c), (d)). The mantles are characterized by either weak oscillatory growth zoning or gray homogeneous (Figure 3(a)-(d)), which im- plies that the source for this granite had experienced simultaneous metamorphism and partial melting. The zircon rims have very high $U$ concentration (>2000 ppm), and due to radioactive decay of $\mathrm{U}$, a large portion of zircon crystals experienced intensive destruction and recrystallization and show sponge-like textures. However, many zircon grains still preserve rims with typical oscillatory growth zoning, characteristics of magmatic zircon. In addition, the outermost part of a few of zircon grains also contain white narrow rims about 5-10 $\mu \mathrm{m}$ thick (Figure 3(a)-(c)), which could be due to hydrothermal or metamorphic events postdated the crystallization.

To constrain more precisely on the crystallization age and possible hydrothermal event of the Paiku tourmaline leucogranite, $\mathrm{U} / \mathrm{Pb}$ analyses were focused on different zircon domains in sample T0659-A. The cores are characterized by (1) relatively low but wide variations in $\mathrm{U}$ (35-814 ppm) and Th (5-153 ppm), respectively, which results in great variations in $\mathrm{Th} / \mathrm{U}$ ratio from 0.02 to 1.65 ; (2) relatively wide range in ${ }^{206} \mathrm{~Pb} /{ }^{238} \mathrm{U}$ age from $297.3 \mathrm{Ma}$ to 1922.4 Ma (Table 1); (3) a cluster of grains with concordant ${ }^{206} \mathrm{~Pb} /$ ${ }^{238} \mathrm{U}$ ages of $470.4-488.2 \mathrm{Ma}$ with a weighted mean age of $483.3 \mathrm{Ma}$; and (4) another cluster at $251.0 \mathrm{Ma}$, the others are discordant due to various degrees of $\mathrm{Pb}$ loss.

Many analyses performed on mantle and a few on rim domains yielded discordant ages with concordance down to $-8 \%$, therefore we choose points with concordance higher than $95 \%$ to calculate meaningful ages. Analyses on the mantles show that they have a relatively wide range of $U$ and Th concentrations from 94 to $2488 \mathrm{ppm}$, and from 4 to $248 \mathrm{ppm}$, respectively, and $\mathrm{Th} / \mathrm{U}$ from 0.01 to 0.11 . The mantles yield ${ }^{206} \mathrm{~Pb} /{ }^{238} \mathrm{U}$ ages from $33.5 \pm 0.2$ Ma to $35.1 \pm 0.7$ Ma (Figure 3(e)) with a cluster around 33.6 Ma. The mean age of 4 points is $33.6 \pm 0.6 \mathrm{Ma}(\mathrm{MSWD}=1.6)$. The mantle domains either with weak oscillatory growth zoning or with
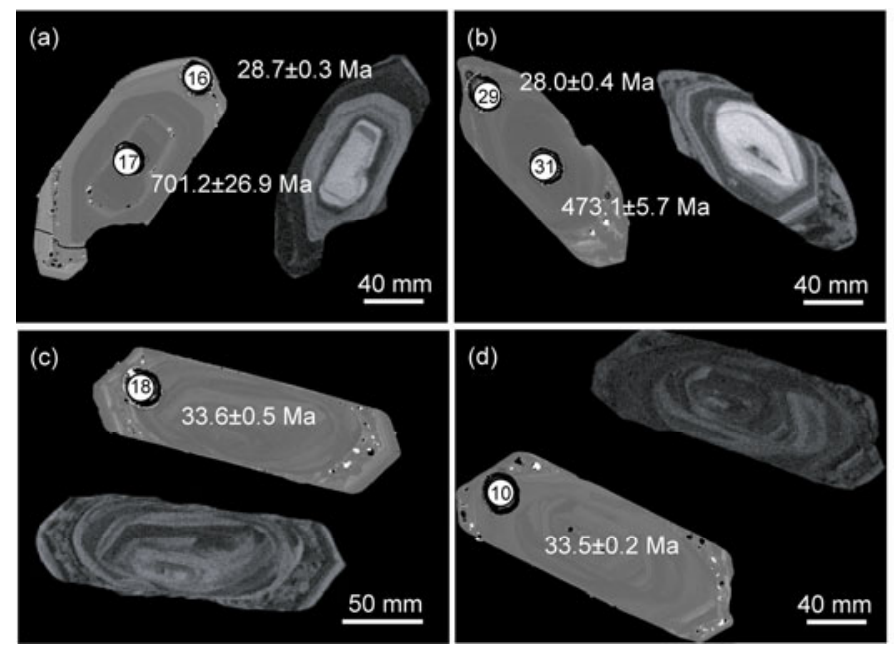

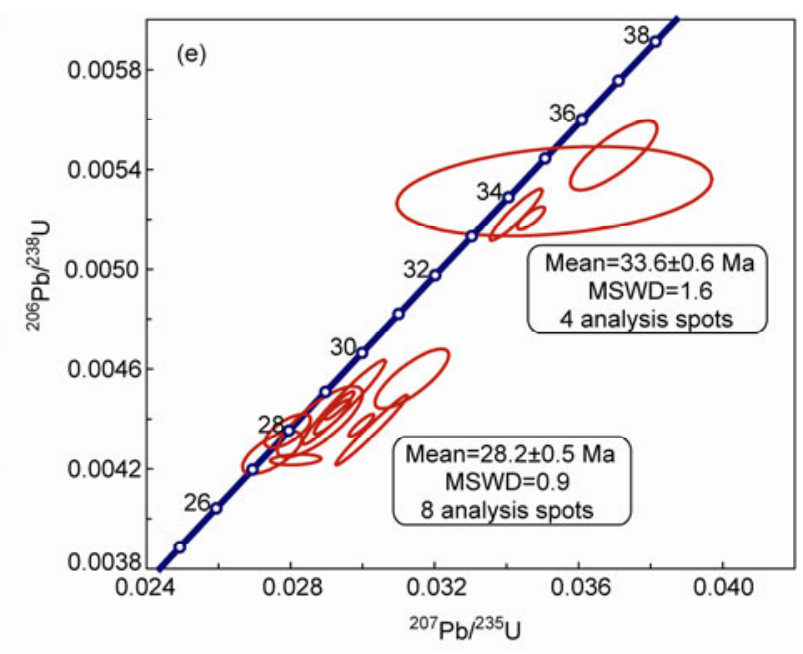

Figure 3 Cathodoluminescence (CL) and Backscatter images (BSE) showing the texture, spot, and respective age of LA-MC-ICP-MS zircon U/Pb dating (a)-(d) and U/Pb concordia diagram (e) for the tourmaline leucogranite T0659-A. 
gray homogeneous texture yield similar ${ }^{206} \mathrm{~Pb} /{ }^{238} \mathrm{U}$ ages, therefore we interpret this age as the timing of high-grade metamorphism and simultaneous parting melting experienced in the source rocks. Except for few zircon grains, the rims with well-developed oscillatory zoning commonly yielded ${ }^{206} \mathrm{~Pb} /{ }^{238} \mathrm{U}$ ages with concordance higher than $95 \%$. U and Th concentrations in the rim are also relatively wide and range from 751 to $10184 \mathrm{ppm}$ and 39 to $553 \mathrm{ppm}$, respectively, which lead to low $\mathrm{Th} / \mathrm{U}$ ratios $(<0.08)$. Eight analyses yield relatively concentrated ${ }^{206} \mathrm{~Pb} /{ }^{238} \mathrm{U}$ ages ranging from 27.3 $\pm 0.1 \mathrm{Ma}$ to $28.7 \pm 0.9 \mathrm{Ma}$ (Figure 3(e)) and a cluster around $28.2 \mathrm{Ma}$ in a $\mathrm{Pb} / \mathrm{U}$ concordia diagram, which define a weighted mean age of $28.2 \pm 0.5 \mathrm{Ma}(\mathrm{MSWD}=0.9)$. Though the rims have low Th/U ratios, well-developed oscillatory overgrowth zoning indicates that they crystallized from granitic melts. Therefore, we interpret this age as the time of crystallization for the Paiku tourmaline leucogranite. Although some ages from the mantle or the rim are similar to data presented as above, they are strongly discordant and plotted to the right of the U/Pb concordia (Figure 3(e)). This suggests that these zircon domains have been influenced by various degrees of $\mathrm{Pb}$ loss due to later hydrothermal events.

Sample T0659-B is a representative sample of two-mica granite that consists of quartz, plagioclase, muscovite, biotite, and accessory zircon, apatite, and monazite. Most of zircon grains in this sample are euhedral to subhedral, long prismatic, 100-150 $\mu \mathrm{m}$ long with aspect ratios commonly of 2.0-3.0. Most zircon grains show a similar core-mantle-rim texture in CL and BSE images (Figure 4(a)-(d)). The cores display weak oscillatory zoning (Figure 4(a),(b)) and are surrounded by mantles with typical oscillatory growth zoning, indicative of magmatic origin, and in turn surrounded by sponge-like (Figure 4(b)) or thin grey rims (Figure 4(a),(c),(d)), whereas a few of zircon grains only display core-rim texture (Figure 4(a),(b)).

To constrain the timing of formation of this leucogranites, $\mathrm{U} / \mathrm{Pb}$ analyses were focused mainly on zircon rims with welldeveloped oscillatory zoning. Similar to those in sample T0659-A, U and Th concentrations in the cores are highly variable and range from 99 to $1085 \mathrm{ppm}$ and from 3 to 329 ppm, respectively, which results in large variations in $\mathrm{Th} / \mathrm{U}$ ratios $(0.02-0.94)$. The cores also yield a relatively wide range of ${ }^{206} \mathrm{~Pb} /{ }^{238} \mathrm{U}$ ages from 322.8 to $911.5 \mathrm{Ma}$ (Table 1). Again, they cluster around $481.3 \mathrm{Ma}$ in a $\mathrm{Pb} / \mathrm{U}$ concordia diagram (Figure 4(e)) and define a weighted mean age of 481.3 $\pm 4.0 \mathrm{Ma}(\mathrm{MSWD}=0.1$ ), whereas spots with ages from 322.8 to $414.7 \mathrm{Ma}$ are discordant due to various degrees of $\mathrm{Pb}$ loss. The mantles with typical oscillatory growth zoning show similar features in U (110-2991 ppm) and Th (2-439 $\mathrm{ppm}$ ) concentrations and $\mathrm{Th} / \mathrm{U}$ ratios (0.01-0.69) to those in the core. Analyses performed on the mantles yield a relatively narrow ${ }^{206} \mathrm{~Pb} /{ }^{238} \mathrm{U}$ age ranging from $19.2 \pm 0.3 \mathrm{Ma}$ to $25.6 \pm 0.3 \mathrm{Ma}$ (Figure 4(f)), which cluster around 19.8 Ma in a $\mathrm{Pb} / \mathrm{U}$ concordia diagram and define a weighted mean age of $19.8 \pm 0.5 \mathrm{Ma}(\mathrm{MSWD}=2.3$ ). Due to the well-developed oscillatory overgrowth zoning, we interpret this age as the
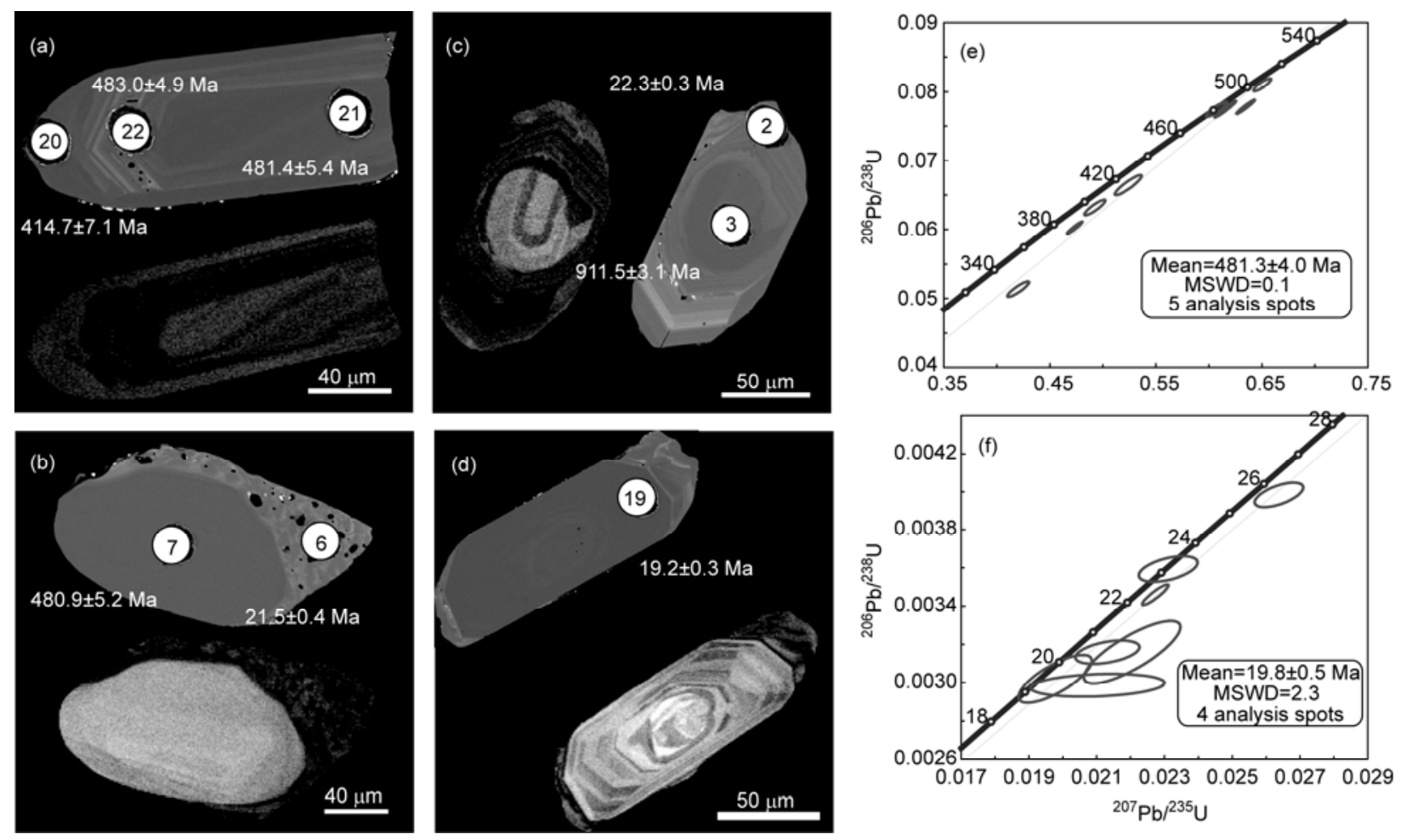

Figure 4 Cathodoluminescence (CL) and Backscatter images (BSE) showing the texture, spot, and respective age of LA-MC-ICP-MS zircon U/Pb dating (a)-(d) and U/Pb concordia diagram (e), (f) for the tourmaline leucogranite T0659-B. 
timing of crystallization to form the Paiku two-mica granite. The rims are sponge-like or grey homogenous, indicating that these zircon grains have been affected by later hydrothermal events.

\subsection{Zircon Hf isotope geochemistry}

We perform in situ zircon $\mathrm{Hf}$ isotope analysis on sample T0659-A and T0659-B in order to characterize their Hf isotope compositions of these two types of leucogranite. Some zircon grains with similar textures have no ${ }^{206} \mathrm{~Pb} /{ }^{238} \mathrm{U}$ ages, they are not shown in Figure 5. For our purpose with a focus on the nature of partial melting to produce the Paiku composite leucogranites pluton, we only discriminate analyses on the rim from those either from core or from mantle. Analytical results of zircon grains from the tourmaline leucogranite show that (1) the magmatic rims are characterized by highly heterogenous $\mathrm{Hf}$ isotope compositions $\left({ }^{176} \mathrm{Hf} /\right.$ ${ }^{177} \mathrm{Hf}(\mathrm{t})=0.28237-0.28267, \varepsilon_{\mathrm{Hf}}(t)=-13.8$ to -2.8$)$, and young crustal modal age with $T_{\mathrm{DM} 1}=857-1283 \mathrm{Ma}$ (Figure 5(a), Table 2), and (2) though the core or mantle show similarly wide range in $\mathrm{Hf}$ isotope compositions and crustal modal ages, they are substantially more negative $\left(\varepsilon_{\mathrm{Hf}}(t)=-24.5\right.$ to -10.5 ) and older $\left(T_{\mathrm{DM} 1}=1169-1662 \mathrm{Ma}\right)$, respectively (Table 2$)$.

In contrast, Hf analyses on zircon grains from the twomica granites show different patterns from those in the
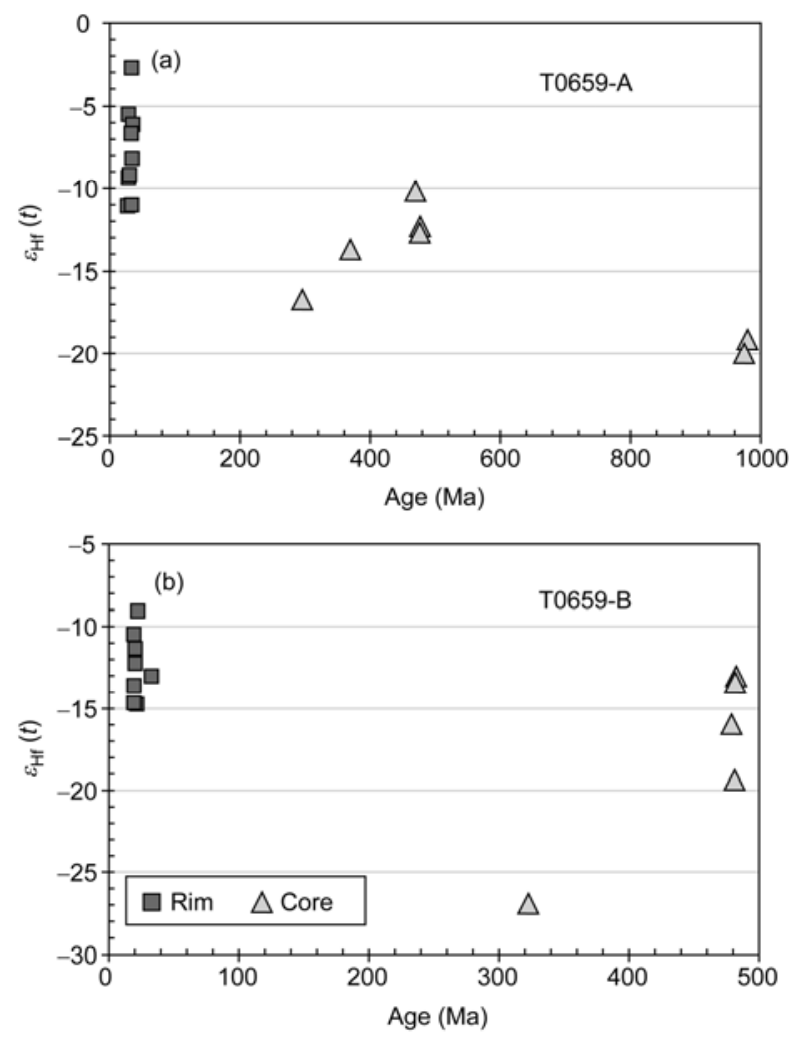

Figure 5 Zircon $\mathrm{U} / \mathrm{Pb}$ ages and $\mathrm{Hf}$ isotope compositions of the tourmaline leucogranite T0659-A (a) and the two-mica granite T0659-B (b) in the Paiku area. tourmaline leucogranites. Major differences include (1) relatively smaller variations in the $\mathrm{Hf}$ isotope compositions with ${ }^{176} \mathrm{Hf} /{ }^{177} \mathrm{Hf}(\mathrm{t})$ from 0.28233 to 0.28249 and $\varepsilon_{\mathrm{Hf}}(t)$ from -15.0 to -9.3 (Figure 5(b), Table 2) and older crustal modal age $T_{\mathrm{DM} 1}$ of 1116-1315 Ma from the magmatic rims; (2) much wider range of $\mathrm{Hf}$ isotope compositons in cores with $\varepsilon_{\mathrm{Hf}}(t)$ from -34.3 to -10.1 and ${ }^{176} \mathrm{Hf} /{ }^{177} \mathrm{Hf}$ ratio from 0.28179 to 0.28247 (Table 2), and relatively older crustal modal age $T_{\mathrm{DM} 1}$ of $1120-2041 \mathrm{Ma}$.

\subsection{Buck-rock major and trace element geochemistry}

Three types of leucogranite in the Paiku pluton show major differences in major as well as in trace element compositions. Major element abundance is listed in Table 3 and is shown graphically in Figure 6. The tourmaline leucogranites have relatively lower $\mathrm{SiO}_{2}(72.5 \%-73.2 \%)$ than two-mica granites and garnet-bearing leucogranite $(73.3 \%-75.0 \%)$, in contrast, the content of $\mathrm{Al}_{2} \mathrm{O}_{3}$ in the tourmaline leucogranite $(>14.8 \%)$ is higher than others with $\mathrm{Al}_{2} \mathrm{O}_{3}$ ranging from $14.3 \%$ to $14.8 \%$ (Figure 6(a)). As compared to other leucogranites, the tourmaline leucogranite have higher $\mathrm{K}_{2} \mathrm{O}$ $(>4.9 \%)$, lower $\mathrm{CaO}(<0.7 \%)$, and similar contents of $\mathrm{Na}_{2} \mathrm{O}$, $\mathrm{FeO}, \mathrm{MgO}$, and $\mathrm{MnO}$ (Table 3). Data presented above indicate that all the leucogranites within the Paiku pluton are of $\mathrm{K}$-rich peraluminous granite with $\mathrm{A} / \mathrm{CNK}>1.1$ and $\mathrm{K}_{2} \mathrm{O}>$ $4.2 \%$.

Similar to major element contents, these leucogranites also show substantial differences in trace element compositions (Figure 7, Table 3). The tourmaline leucogranites contain strikingly highest B (1033-1089 ppm) but lowest $\mathrm{Sr}$ concentration $(<39 \mathrm{ppm})$, and the garnet-bearing leucogranite have the lowest $\mathrm{Ba}$ concentration among these rocks (Figures 7 and 8(a)). These leucogranites also display similar primitive mantle normalized trace element distribution patterns (Figure 7(a)) characterized by positive anomalies of $\mathrm{K}$ and $\mathrm{Rb}$ but negative anomalies of $\mathrm{Nb}$, $\mathrm{Ti}, \mathrm{Sr}$ and $\mathrm{Ba}$. Interestingly, the tourmaline leucogranite show strong positive $\mathrm{P}$ anomalies in contrast with negative anomalies in the other types of leucogranite.

All these leucogranites are enriched in light rare earth elements (LREE) and show pronounced negative Eu anomalies except for T0659-12, among which the garnet-bearing ones have the greatest magnitude of negative Eu anomalies. However, heavy rare earth element (HREE) contents in these leucogranites are different. Garnet-bearing leucogranites are weakly enriched in HREE with $(\mathrm{Gd} / \mathrm{Yb})_{N}=0.6-1.0$, whereas the others are weakly depleted in HREE with $(\mathrm{Gd} /$ $\mathrm{Yb})_{N}=1.5-1.9$.

\subsection{Sr and Nd isotope geochemistry}

In order to characterize the source regimes for these leucogranites within the Paiku pluton, we conduct $\mathrm{Sr}$ and $\mathrm{Nd}$ isotope analyses on the tourmaline leucogranite and two- 

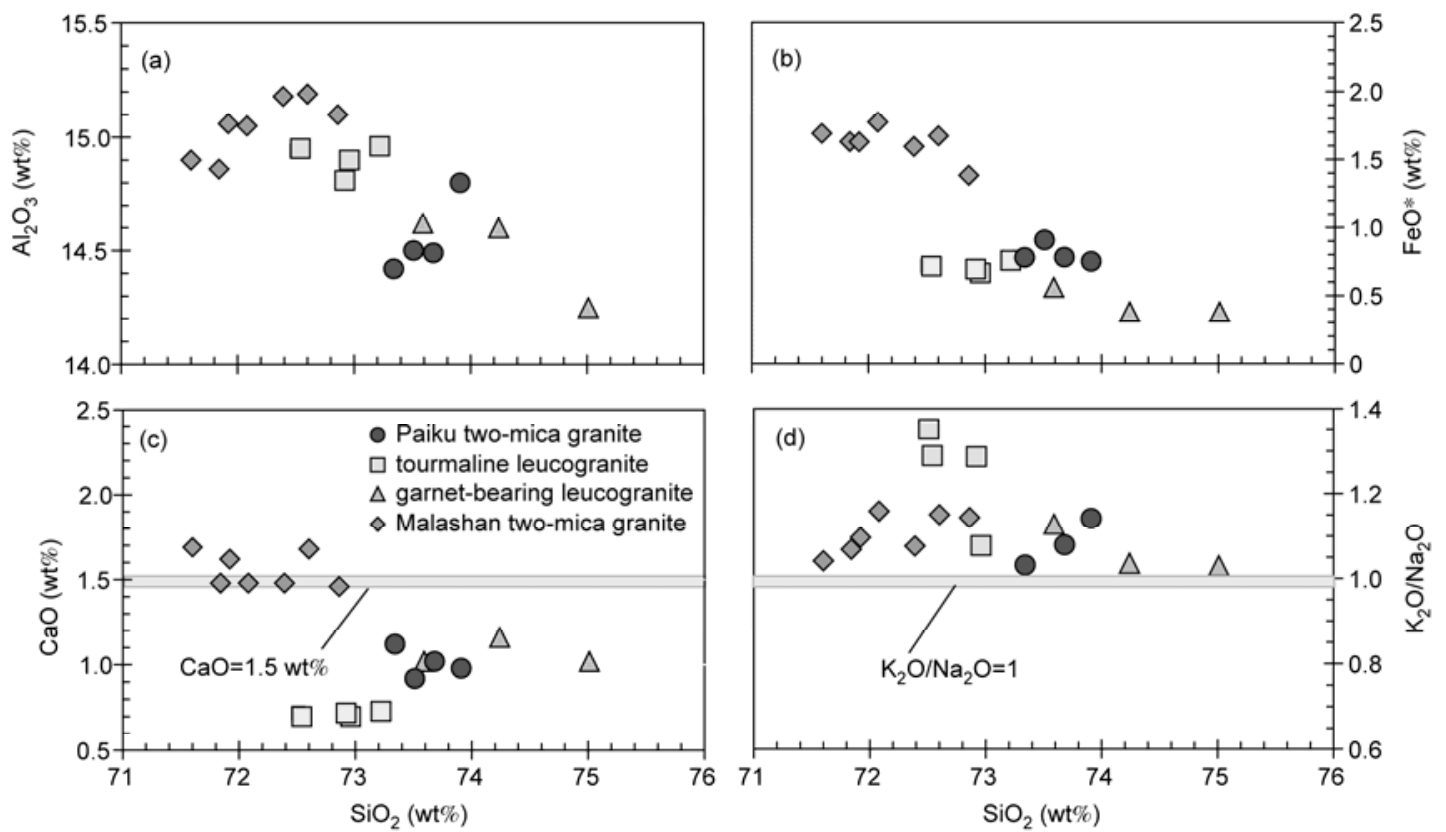

Figure 6 Selected major oxides of (a) $\mathrm{Al}_{2} \mathrm{O}_{3}$, (b) FeO* and (c) $\mathrm{CaO}$, and (d) $\mathrm{K}_{2} \mathrm{O} / \mathrm{Na}_{2} \mathrm{O}$ ratio plotted against $\mathrm{SiO}_{2}$ for the Malashan two-mica granite and the Paiku composite leucogranite.
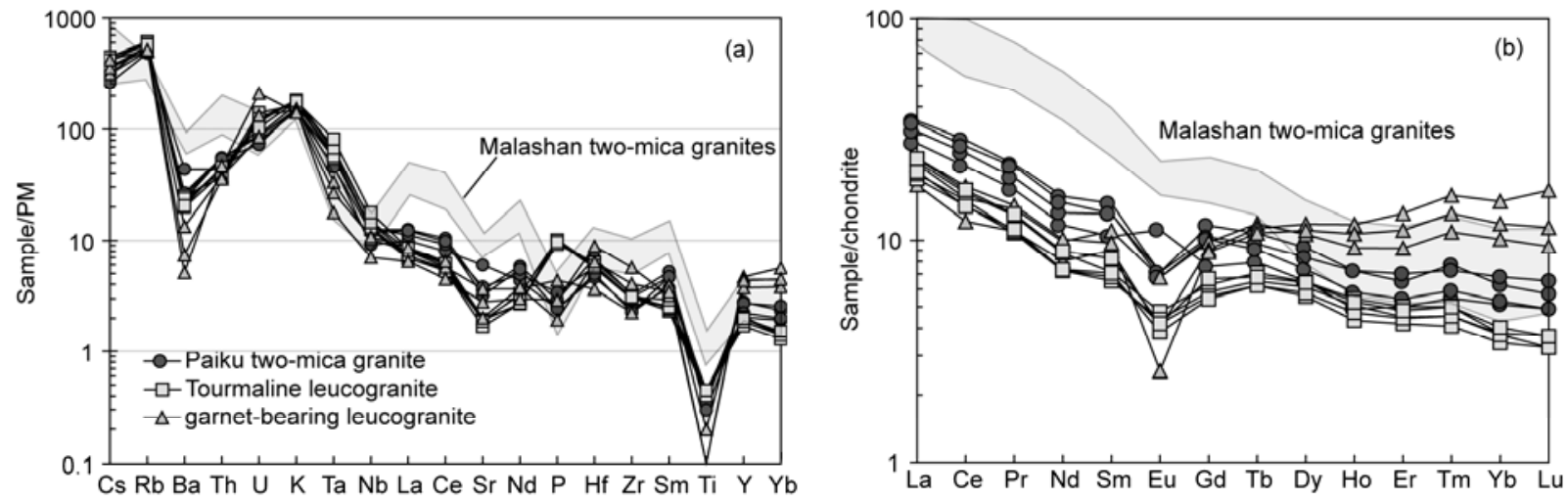

Figure 7 Primitive mantle (PM)-normalized trace element (a) and chondrite-normalized rare earth element (b) distribution patterns for the Malashan twomica granite and the Paiku composite leucogranite. Primitive mantle and chondrite normalization values are from [43].
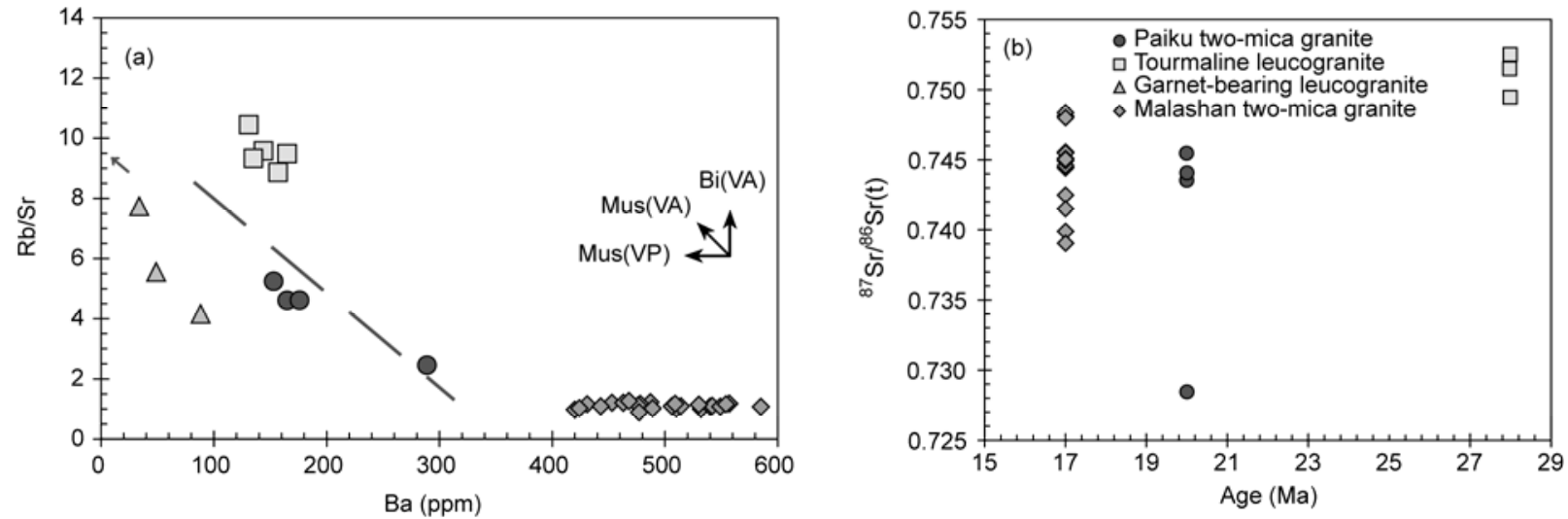

Figure $8 \mathrm{Rb} / \mathrm{Sr}$ vs. Ba diagram (a) and ${ }^{87} \mathrm{Sr} /{ }^{86} \mathrm{Sr}$ vs. age diagram (b) for the Malashan two-mica granite and the Paiku leucogranite. 
mica granite. Analytical data are listed in Table 4. Tourmaline leucogranites have relatively higher $\mathrm{Rb}(>338.0 \mathrm{ppm})$ and lower $\mathrm{Sr}(<38.9 \mathrm{ppm}), \mathrm{Sm}(<4.1 \mathrm{ppm})$ and $\mathrm{Nd}(<1.2$ $\mathrm{ppm}$ ) than those in the two-mica granite. The initial Sr isotopic compositions in the tourmaline leucogranites with ${ }^{87} \mathrm{Sr} /{ }^{86} \mathrm{Sr}(\mathrm{t})=0.7495-0.7525$ are higher than in the two-mica granites with ${ }^{87} \mathrm{Sr} /{ }^{86} \mathrm{Sr}(\mathrm{t})=0.7285-0.7454$ (Figure 8(b)), whereas both leucogranites are characterized by similarly unradiogenic initial $\mathrm{Nd}$ isotopic compositions with $\varepsilon_{\mathrm{Nd}}(t)=-13.0$ to -13.3 in the tourmaline leucogranites and $\varepsilon_{\mathrm{Nd}}(t)=-13.4$ to -13.9 in the two-mica granites, respectively.

\section{Discussions}

\subsection{Timing of crustal anatexis in the Paiku composite leucogranitic pluton}

Previous studies considered the Paiku leucogranitic pluton as a single pluton [24-26], and reported its crystalline ages of 22.2-16.2 Ma [25]. Such a wide age span could be due to analysis on zircon domains straddling cross different overgrowth zoning. Field investigations, petrographic examinations (Figure 2), geochemical analyses (Figures 6-8) and updated zircon $\mathrm{U} / \mathrm{Pb}$ dating (Figures 3-5) all demonstrate that the Paiku pluton is a composite pluton consisting of tourmaline leucogranite, two-mica granite, and garnet-bearing leucogranite.

Zircon grains in the tourmaline leucogranite show a wellpreserved core-mantle-rim texture. Inherited cores show two dominant age groups at $\sim 483.3$ and $\sim 851.0 \mathrm{Ma}$. Mantles with ${ }^{206} \mathrm{~Pb} /{ }^{238} \mathrm{U}$ age of $33.6 \pm 0.6 \mathrm{Ma}$ are characterized by either weak oscillatory overgrowth zoning indicative of zircon growth from granitic melts or by grey homogenous texture from metamorphic recrystallization (Figure 3(a)-(d)) and low $\mathrm{Th} / \mathrm{U}$ ratios $(<0.11)$. The co-existence of these zircon overgrowth textures in the mantle domains at 33.6 \pm 0.6 $\mathrm{Ma}$ indicates that the source regime for the tourmaline leucogranite had experienced metamorphism under P-T conditions higher enough to induce partial melting at the same time. This event could correspond to crustal anatexis at $\sim 35.3$ Ma during the tectonic transition from compressive shortening to extension in the Yardoi dome at the eastmost of NHGD [12], migmatization at $35.0 \pm 0.8 \mathrm{Ma}$ in the Mabja Dome [19], and the earliest phase of partial melting at $36.5 \pm 2.2$ Ma recorded in the deformed granites within the STDS in the Gyirong areas [20]. Similar to zircon grains from leucogranites along the Himalayan belt, zircons from sample T0659-A also contain up to $2000 \mathrm{ppm} \mathrm{U}$. Due to radioactive decay of $U$, such zircons experienced extensive destruction and recrystallization and develop sponge-like textures. However, the well-developed typical oscillatory overgrowth zoning in most rims indicates that they crystallized from granitic melts. These domains yield relatively low $\mathrm{Th} / \mathrm{U}$ ratios from 0.02 to 0.08 , characteristics of anatectic zircons. Therefore, The ${ }^{206} \mathrm{~Pb} /{ }^{238} \mathrm{U}$ age of $28.2 \pm 0.5 \mathrm{Ma}$ represents the timing of crystallization to form the tourma-

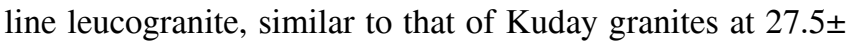
$0.5 \mathrm{Ma}$ in the central NHGD [44].

Zircons in the two-mica granites also show a core-mantlerim texture. The inherited zircon cores show weak oscillatory zoning (Figure 4(a), (b)) and yield dominant ${ }^{206} \mathrm{~Pb} /{ }^{238} \mathrm{U}$ age group at $481.3 \pm 4.0 \mathrm{Ma}$. This indicates that the source regime consists of major components that contributed from 481 Ma magmatic events. The mantle domains are of typical oscillatory overgrowth zoning (Figure 4(c), (d)), characteristics of magmatic origin, and yield ${ }^{206} \mathrm{~Pb} /{ }^{238} \mathrm{U}$ ages clustered at $19.8 \pm 0.5 \mathrm{Ma}$. This age represents the time to crystallize the two-mica granite. However, sponge-like textures and thin grey homogenous rims suggest that these rocks have been affected by later hydrothermal activities.

In summary, data presented above indicate that the tourmaline leucogranite formed at $28.2 \pm 0.5 \mathrm{Ma}$ and its source regime experienced high metamorphism and simultaneous partial melting at 33.6 $\pm 0.6 \mathrm{Ma}$, whereas the two-mica granite formed at $19.8 \pm 0.5 \mathrm{Ma}$. Therefore, the Paiku leucogranitic pluton is a composite pluton built by episodic intrusions over a time span of $\sim 8$ myr.

\subsection{Source rock of the Paiku composite leucogranite}

Date presented above indicate that: (1) the Paiku leucogranite is a composite pluton and consists of tourmaline leucogranite, two-mica granite and garnet-bearing leucogranite; (2) the tourmaline leucogranite formed earlier at $\sim 28.2 \mathrm{Ma}$ and its source rock experienced high metamorphism and simultaneous anatexis at $\sim 33.6 \mathrm{Ma}$, in contrast to much later for the two-mica granite at $\sim 19.8 \mathrm{Ma}$; (3) though the amount of analyses on the zircon cores are too limited to fully cover the age spectrum of inherited zircon, two types of leucogranite both contain a large number of $\sim 480$ Ma inherited zircons. This implies that their source rocks might have major contributions from the Ordovician magmatic event, possibly in a continental arc environment [45]; (4) the bulkrock initial $\mathrm{Sr}$ isotope compositions and zircon $\mathrm{Hf}$ isotope compositions in the tourmaline leucogranites are higher than those in the two-mica granites; (5) all three types of leucogranite are of K-rich peraluminous with $\mathrm{A} / \mathrm{CNK}>1.1$ and show slight differences in major element compositions (e.g. $\mathrm{SiO}_{2}, \mathrm{Al}_{2} \mathrm{O}_{3}$, and $\mathrm{CaO}$ ); (6) the tourmaline leucogranites have extraordinary high $\mathrm{B}$ concentrations and positive $\mathrm{P}$ anomalies; and (7) both the tourmaline leucogranites and the two-mica granites are enriched in LREE, but depleted in HREE and show negative Eu anomalies, in contrast, garnet-bearing leucogranites are not only enriched in LREE but also slightly enriched in HREE and show strongest negative $\mathrm{Eu}$ anomalies among all these rocks.

Previous studies on the timing of crustal anatexis in the Himalayan orogenic belt indicated that leucogranites formed at 27-10 Ma in the NHGD and the HHCS are typical S-type granites, derived from muscovite dehydration 
melting of metapelites and characterized by high initial ${ }^{87} \mathrm{Sr} /{ }^{86} \mathrm{Sr}$ ratios of $0.7300-0.7800$ and low $\varepsilon_{\mathrm{Nd}}$ from -10 to $-15[1-7,16,46,47]$. Experimental results [6,7], theoretic calculations [22,23] and field investigations [4,16,18] all suggest that fertile metapelites could undergo progressive partial melting with variations in temperature, pressure, and water content, which leads to the formation of granites with different geochemical characteristics in major and trace element as well as in isotope (e.g. $\mathrm{Sr}, \mathrm{Nd}$ ) geochemistry. Metapelites rich in mica, plagioclase, and quartz are fertile crustal material and could produce granitic melts through muscovite- or biotite-melting reactions at fluid-present as well as fluid-absent conditions. The degree of melting at optimum P-T-X conditions can amount to $40 \%$, but it decreases significantly at low temperature of $\sim 700^{\circ} \mathrm{C}$. Through continuous or discontinuous melting reactions, melts from the same metapelite could potentially show complex $\mathrm{Rb}-\mathrm{Sr}$ system relationship [22,48]. Recent petrologic and geochemical studies on the mid-Miocene Malashan TMG demonstrate that they were derived from fluxed melting of muscovite [17]. These granites are characterized by higher contents of $\mathrm{CaO}(>1.5 \%$, Figure 6) and $\mathrm{Ba}$ (Figure 7), but lower and nearly constant $\mathrm{Rb} / \mathrm{Sr}$ ratios $(<1.4)$ relative to large variations in $\mathrm{Ba}$ concentrations (Figure 8(a)). Leucogranites in the Paiku composite pluton show different geochemical nature from those in the Malashan TMG, but similar to typical Himalayan Cenozoic leucogranites (Figures 6 and 7). Negative correlationship between $\mathrm{Rb} / \mathrm{Sr}$ and $\mathrm{Ba}$ (Figure 8(a)) in the Paiku leucogranites suggests that they were derived from muscovite dehydration melting of metapelites. The initial $\mathrm{Sr}$ and $\mathrm{Nd}$ isotope compositions in these Paiku leucogranites are different. Sr isotope compositions in the tourmaline leucogranites are slightly higher than those in the two-mica granites, but they both have similarly low $\varepsilon_{\text {Nd }}$ values. Factors that could contribute to the observed geochemical and isotopic features in the Paiku leucogranites include: (1) distinct source rocks, (2) difference in proportion of muscovite involved in the partial melting reactions, or (3) both effects.

Experimental results and theoretic calculations demonstrate that as compared with muscovite dehydration melting, proportion of muscovite involved in the fluxed melting of muscovite reactions decrease substantially accompanied by increase in feldspar components, which results in melts with enhanced contents of $\mathrm{Sr}$, but lower $\mathrm{Rb}, \mathrm{Rb} / \mathrm{Sr}$ ratios and $\mathrm{Sr}$ isotope compositions $[7,22,44]$. As compared with the Paiku two-mica granites, the tourmaline leucogranites have higher $\mathrm{Rb} / \mathrm{Sr}$ ratios and $\mathrm{Sr}$ isotope compositions, implying that much more muscovite involved in the dehydration melting of metapelites to generate the tourmaline leucogranites. However, only differences in partial melting reactions can not explain the large variations in $\mathrm{Sr}$ isotope compositions of the two-mica granites ranging from 0.728477 to 0.745432 and relatively lower $\mathrm{Hf}$ isotope compositions. Therefore, except for distinct crystallization ages of the two types of leucogranites, their source rocks maybe different.

If the tourmaline leucogranites and the two-mica granites have same source rock, they should have show the following features including (1) similar age spectrum in inherited zircon cores; (2) higher initial $\mathrm{Sr}$ but lower initial $\mathrm{Nd}$ isotope compositions in the two-mica granites than those in the tourmaline leucogranite; and (3) Hf isotope compositions in magmatic zircon rims should increase with the decrease of crystallization ages. The zircon textures (Figures 3 and 4) and $\mathrm{U} / \mathrm{Pb}$ ages (Figure 9, Table 1) indicate that both leucogranites contain $\sim 480$ Ma inherited zircons, but the tourmaline leucogranites contain much older (up to 1922.4 Ma) inherited zircon grains than the two-mica granites. In addition, Hf isotope compositions in inherited zircons from both leucogranites are substantially different (Figure 5). Inherited zircons from the tourmaline leucogranites have higher $\varepsilon_{\mathrm{Hf}}(t)$ ranging from -24.5 to -10.5 and younger crustal modal ages of 1169-1662 Ma in contrast with much lower $\varepsilon_{\mathrm{Hf}}(t)$ and older crustal modal age of inherited zircons in the twomica granite. Differences in $\mathrm{Sr}$ and $\mathrm{Hf}$ isotope compositions between the tourmaline leucogranites and the two-mica granites (Figures 5 and 8) indicate that they could not share the same source rocks, consistent with inference drawn from $\mathrm{Rb} / \mathrm{Sr}-\mathrm{Ba}$ systematics. However, similar $\mathrm{Nd}$ isotope compositions in both leucogranites imply that $\mathrm{Sm}-\mathrm{Nd}$ isotope system is more robust than $\mathrm{Rb}-\mathrm{Sr}$ system which is more susceptible to be perturbed by metamorphism or hydrothermal reactions. Within the Himalayan orogenic belt, data from literature [13] and to be published of metamorphic rocks demonstrate that the mineral assemble and bulkrock major and trace element compositions of metapelites
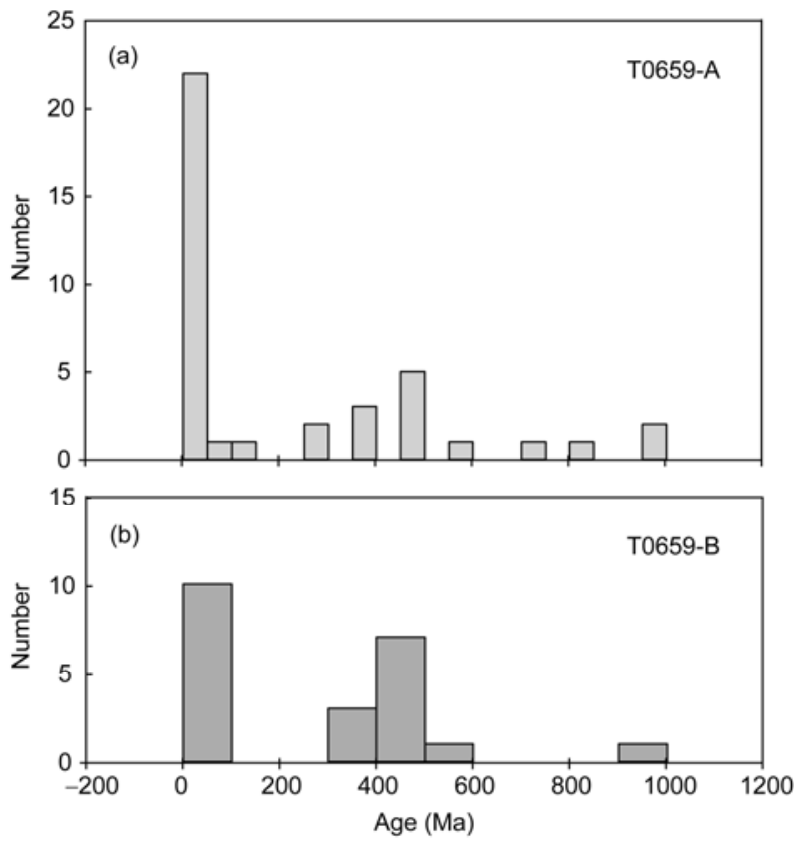

Figure 9 Age comparison between tourmaline leucogranite T0659-A (a) and two-mica granite T0659-B (b) in the Paiku area. 
are highly heterogeneous. Such metapelites could potentially undergo partial melting at various temperature and pressure conditions during the tectonic evolution of the Himalayan orogen and produced distinct leucogranitic melts. Data presented above demonstrate that metasedimentary rocks, presumably at the middle to lower crustal levels, had experienced episodic melting at $\sim 33.6, \sim 28.2$, and $\sim 19.8 \mathrm{Ma}$, respectively, among which the later two correspondently produced the tourmaline leucogranite and two-mica granite in the Paiku pluton. Despite difference in the formation ages, different source regimes and different partial melting reactions together lead to the pronounced geochemical heterogeneity in these leucogranites.

\subsection{The implication of melting in Paiku composition leucogranite}

Both detailed structural investigations and geochronologic studies indicate that the Malashan, Kangmar, and Mabja gneiss domes had experienced similar types of metamorphism and deformation [19,24-26,32,49,50], which strongly suggest that they were formed in the same tectonic setting [21]. Lee et al. [19] documented that the migmatites in the Mabja gneiss dome had experienced partial melting at 35.0 $\pm 0.8 \mathrm{Ma}$. Within the Yardoi gneiss dome, recent studies found a suite of $\sim 43 \mathrm{Ma}$ high $\mathrm{Sr} / \mathrm{Y}$ two-mica granites and $\sim 35 \mathrm{Ma}$ high $\mathrm{Na} / \mathrm{K}$ leucogranites [12,13]. These granites represent the melting products from amphibolite at thickened crustal conditions and during the tectonic transition from compressive shorting to extension in the Himalayan orogen, respectively. In addition, syn-collision leucogranites within the STDS in the Gyirong area also record partial melting at $\sim 36 \mathrm{Ma}[20]$. These studies suggest that there is strong genetic relationship between middle to lower crustal anatexis represented by formation of granites and large scale of extensional deformation. Initiation of the STDS could be triggered by these $\sim 35$ Ma melting processes and traced back to $\sim 35 \mathrm{Ma}[12,19-21]$. In this contribution, geochronological and geochemical characteristics of the Paiku leucogranites in the Malashan area indicate that crustal anatexis in the western NHGD could be as early as 33.6 \pm 0.6 Ma or older, similar to the central and eastern NHGD. Partial melting of distinct metapelites in response to the evolving P-T-X conditions during the tectonic evolution of large collisional orogenic belts indeed could generate a spectrum of granitic melts with distinct geochemical as well as isotopic characteristics. The earliest anatexis both at the hanging wall and footwall of the STDS in the Himalaya collisional belt occurred at $35 \mathrm{Ma}$, indicating that $\sim 35 \mathrm{Ma}$ partial melting may be the major factor to initiate the STDS and in turn leads to tectonic transition from compressive shortening to extension. Within the Tibetan plateau and adjacent areas, initial movement of the Karakorum Fault [51], large displacement along the Altyn Tagh fault [52,53], strike-slip movements in the Red River belt [54], and aridification of the Tibetan plateau linked to global cooling [55] all occurred at $\sim 35 \mathrm{Ma}$. All these studies indicate that $\sim 35 \mathrm{Ma}$ tectonic events in the Tibetan plateau are widespread. Under intensive compression, the southern Tibet experienced tectonic transition at $\sim 35 \mathrm{Ma}$ from compressive shortening to extension. In the Malashan area, the tourmaline leucogranite and two-mica granite formed at $\sim 28.2$ and $\sim 19.8 \mathrm{Ma}$, respectively, corresponding to two main phases of partial melting at $26 \mathrm{Ma}$ and at 21-20 Ma recorded in the syn-collision granites within the STDS [20] and coinciding with the active time of STDS from 25 to $12 \mathrm{Ma}$ [56-60]. Therefore, formation of the Oligocene and mid-Miocene leucogranites in the Paiku area suggests that movement along the STDS not only triggered rapid exhumation of high grade metamorphic rocks but also induced large-scale crustal anatexis.

Combined with literature data, we suggest that prior to $35 \mathrm{Ma}$, the Himalayan orogenic belt underwent intensive shortening accompanied by partial melting of middle-lower crustal material. These melting processes effectively changed physical properties of deep crustal rocks and triggered the tectonic transition of the Himalayan orogen from compression to extension and initiated the movement of the STDS. With further extension along the STDS, rapid exhumation of deep crustal materials resulted in the large-scale decompression melting of metapelites and the formation of typical Himalayan S-type granites with ages <30 Ma [13,19-21]. The Oligocene ( $28 \mathrm{Ma})$ and mid-Miocene ( 20 Ma) leucogranites in the Paiku area represent the melting products from metapelites associated with the active movement along the STDS.

We thank the editors for handling this manuscript carefully and two anonymous reviews for their constructive comments which greatly improved the manuscript. This work was supported by the National Basic Research Program of China (2011CB403102) and the National Natural Science Foundation of China (41073024 and 41273034).

1 Harris N, Massey J. Decompression and anatexis of Himalayan metapelites. Tectonics, 1994, 13: 1537-1546

2 Harris N, Ayres M, Massey J. Geochemistry of granitic melts produced during the incongruent melting of muscovite-implications for the extraction of Himalayan leucogranite magmas. J Geophys Res, 1995, 100: 15767-15777

3 Harrison T M, Oscar M L, Marty G, et al. New insight into the origin of two contrasting Himalayan granite belts. Geology, 1997, 25: 899902

4 Zhang H F, Harris N, Parrish R, et al. Causes and consequences of protracted melting of the mid-crust exposed in the North Himalayan antiform. Earth Planet Sci Lett, 2004, 228: 195-212

5 Le Fort P. Manaslu leucogranite: A collision signature of the Himalaya a model for its genesis and emplacement. J Geophys Res, 1981, 86: $10545-10568$

6 Patiño Douce A E, Harris N. Experimental constraints on Himalayan Anatexis. J Petrol, 1998, 39: 689-710

7 Knesel K M, Davidson J P. Insight into collisional magmatism from isotopic fingerprints of melting reactions. Science, 2002, 296: 22062208

8 Aikman A B, Harrison T M, Ding L. Evidence for Early (>44 Ma) Himalayan Crustal Thickening, Tethyan Himalaya, southeastern Tibet. 
Earth Planet Sci Lett, 2008, 274: 14-23

9 Gao L E, Zeng L S, Liu J, et al. Early Oligocene Na-rich peraluminous leucogranites in the Yardoi gneiss dome, southern Tibet: Formation mechanism and tectonic implications (in Chinese). Acta Petrol Sin, 2009, 25: 2289-2302

10 Gao L E, Zeng L S, Hu G Y. High Sr/Y two-mica granite from Quedang, southern Tibet, China: Formation mechanism and tectonic implications (in Chinese). Geol Bull Chin, 2010, 29: 214-226

11 Xie K J, Zeng L S, Liu J. et al. Late-Eocene Dala adalitic granite, southern Tibet and geological implication (in Chinese). Acta Petrol Sin, 2010, 26: 1016-1026

12 Zeng L S, Liu J, Gao L E, et al. Early Oligocene crustal anatexis in the Yardoi gneiss dome, southern Tibet and geological implications. Chin Sci Bull, 2009, 54: 104-112

13 Zeng L S, Gao L E, Xie K J, et al. Mid-Eocene high Sr/Y granites in the Northern Himalayan Gneiss Domes: Melting thickened lower continental crust. Earth Planet Sci Lett, 2011, 303: 251-266

14 Hou Z Q, Zheng Y C, Zeng L S, et al. Eocene-Oligocene granitoids in southern Tibet: Constraints on crustal anatexis and tectonic evolution of the Himalayan orogen. Earth Planet Sci Lett, 2012, 349-350: $38-52$

15 Prince C, Harris N, Vance D. Fluid-enhanced melting during prograde metamorphism. J Geol Soc Lon, 2001, 158: 233-241

16 King J, Harris N, Argles T, et al. The contribution of crustal anatexis to the tectonic evolution of Indian crust beneath southern Tibet. Geol Soc Amer Bull, 2011, 123: 218-239

17 Gao L E, Zeng L S. Mid-Miocene two-mica granites in the Malashan gneiss dome, south Tibet: Geochemical characteristics and formation mechanism. Abstract presented at 2011 AGU Fall Meeting, 2011, Dec 5-9, San Francisco

18 Zeng L S, Gao L E, Dong C Y, et al. High-pressure melting of metapelite and the formation of Ca-rich granitic melts in the Namche Barwa Massif, southern Tibet. Gondwana Res, 2012, 21: 138-151

19 Lee J, Whitehouse M J. Onset of mid-crustal extensional flow in southern Tibet: Evidence from U/Pb zircon ages. Geology, 2007, 35: $45-48$

20 Yang X Y, Zhang J J, Qi G W. Structure and deformation around the Gyirong basin, northern Himalaya, and onset of the south Tibetan detachment system. Sci China Ser D-Earth Sci, 2009, 52: 1046-1058

21 Zhang J J, Yang X Y, Qi G W, et al. Geochronology of the Malashan dome and its application in formation of the Southern Tibet detachment system (STDS) and Northern Himalayan gneiss domes (NHGD) (in Chinese). Acta Petrol Sin, 2011, 27: 3535-3544

22 Zeng L S, Asimow P, Saleeby J B. Coupling of anatectic reactions and dissolution of accessory phases and the $\mathrm{Sr}$ and $\mathrm{Nd}$ Isotope systematics of anatectic melts from a metasedimentary source. Geochim Cosmochim Acta, 2005, 69: 3671-3682

23 Zeng L S, Saleeby J B, Asimow P. Nd isotope disequilibrium during crustal anatexis: A record from the Goat Ranch migmatite complex, southern Sierra Nevada batholith, California. Geology, 2005, 33: $53-56$

24 Aoya M, Wallis S R, Kawakami T, et al. The Malashan metamorphic complex in southern Tibet: Dominantly top-to the-north deformation and intrusive origin of its associated granites. Himalayan Journal of Science, 2004, 2: 92

25 Kawakami T, Aoya M, Wallis S R, et al. Contact metamorphism in the Malashan Dome, North Himalayan gneiss domes, southern Tibet: an example of shallow extensional tectonics in the Tethys Himalaya. J Metamorphic Geol, 2007, 25: 831-853

26 Aoya M, Wallis S R, Terada K, et al. North-south extension in the Tibetan crust triggered by granite emplacement. Geology, 2005, 33: 853-856

27 Debon F, Le Fort P, Sheppard S, et al. The four plutonic belts of the Transhimalaya-Himalaya: A chemical, mineralogical, isotopic, and chronological synthesis along a Tibet-Nepal Section. J Petrol, 1986, 27: $219-250$

28 Harrison T M, Grove M, Lovera O M, et al. The origin of Himalayan anatexis and inverted metamorphism: Models and constraints. J Asian Earth Sci, 1999, 17: 755-772
29 Gao L E, Zeng L S, Xie K J. Eocene high grade metamorphism and crustal anatexis in the North Himalaya Gneiss Domes, Southern Tibet. Chin Sci Bull, 2012, 57: 639-650

30 Schärer U, Xu R, Allegre C. U-(Th)-Pb systematics and ages of Himalayan leucogranites, south Tibet. Earth Planet Sci Lett, 1986, 77: 35-48

31 Pan G T, Ding J. 1:1500000 Geologic map of the Tibetan Plateau and adjacent areas. 2004

32 Lee J, Hacker B R, Dinklage W S, et al. Evolution of the Kangmar dome, southern Tibet: Structural, petrologic and thermochronologic constraints. Tectonics, 2000, 19: 872-895

33 Hou K J, Li Y H, Tian Y Y. In situ U-Pb zircon dating using laser ablation-multi ion couting-ICP-MS. Mineral Deposits, 2009, 28: $481-492$

34 Nasdala L, Hofmeister W, Norberg N, et al. Zircon M257-a homogeneous natural reference material for the ion microprobe $\mathrm{U}-\mathrm{Pb}$ analysis of zircon. Geostand Geoanal Res, 2008, 32: 247-265

35 Jackson S E, Pearson N J, Griffin W L, et al. The application of laser ablation-inductively coupled plasma-mass spectrometry to in situ U-Pb zircon geochronology. Chem Geol, 2004, 211: 47-69

36 Liu Y S, Gao S, Hu Z C, et al. Continental and oceanic crust recycling-induced melt-peridotite interactions in the Trans-North China Orogen: $\mathrm{U}-\mathrm{Pb}$ dating, $\mathrm{Hf}$ isotopes and trace elements in zircons from mantle xenoliths. J Petrol, 2010, 51: 537-571

37 Ludwig K R. ISOPLOT: A geochronological toolkit for Microsoft Excel. Berkeley Geochronol Center Spec Publ, 2003, 4: 71

38 Hou K J, Li Y H, Zou T R, et al. Laser ablation-MC-ICP-MS technique for $\mathrm{Hf}$ isotope microanalysis of zircon and its geological applications (in Chinese). Acta Petrol Sin, 2007, 23: 2595-2604

39 Chu N C, Taylor R N, Chavagnac V, et al. Hf isotope ratio analysis using multi-collector inductively coupled plasma mass spectrometry: An evaluation of isobaric interference corrections. J Anal At Spectrom, 2002, 17: 1567-1574

40 Wu F Y, Yang Y H, Xie L W, et al. Hf isotopic compositions of the standard zircons and baddeleyites used in $\mathrm{U}-\mathrm{Pb}$ geochronology. Chem Geol, 2006, 234: 105-126

41 Morel M L A, Nebel O, Nebel-Jacobsen Y J, et al. Hafnium isotope characterization of the GJ-1 zircon reference material by solution and laser-ablation MC-ICPMS. Chem Geol, 2008, 255: 231-235

42 Sláma J, Kosler J, Condon D J, et al. Plesovice zircon: A new nature reference material for $\mathrm{U}-\mathrm{Pb}$ and $\mathrm{Hf}$ isotopic microanalysis. Chem Geol, 2008, 249: 1-35

43 Sun S S, McDonough W F. Chemical and isotopic systematics of oceanic basalts: Implications for mantle composition and processes. Geol Soc Spec Publ, 1989, 42: 313-345

44 Zhang H F, Harris N, Parrish R, et al. U-Pb ages of Kude and Sajia leucogranites in Sajia dome from North Himalaya and their geological implications. Chin Sci Bull, 2004, 49: 2087-2092

45 Cawood P A, Buchan C. Linking accretionary orogenesis with supercontinent assembly. Earth-Sci Rev, 2007, 82: 217-256

46 Daniel C, Vidal P, Fernandez A, et al. Isotopic study of the Manaslu granite (Himalaya, Nepal): Inferences of the age and source of Himalayan leucogranites. Contrib Mineral Petrol, 1987, 96: 78-92

47 Inger S, Harris N. Geochemical Constraints on Leucogranite Magmatism in the Langtang Valley, Nepal Himalaya. J Petrol, 1993, 34: 345-368

48 Harris N B W, Inger S. Trace element modeling of pelite-derived granites. Contrib Mineral Petrol, 1992, 110: 46-56

49 Lee J, Hacker B, Wang Y. Evolution of North Himalayan Gneiss Domes: Structural and metamorphic studies in Mabja Dome, southern Tibet. J Struct Geol, 2004, 26: 2297-2316

50 Lee J, McClelland W, Wang Y, et al, Oligocene-Miocene middle crustal flow in southern Tibet: Geochronologic studies in Mabja Dome. Geol Soc Spec Publ, 2006, 268: 445-470

51 Li H B, Valli F, Liu D Y, et al. Initial movement of the Karakorum Fault in western Tibet: Constraints from SHRIMP U-Pb dating of zircon. Chin Sci Bull, 2008, 52: 1089-1100

52 Meng Q R, Hu J M, Yang F Z. Timing and magnitude of displacement on the Altyn Tagh fault: Constraints from stratigraphic correla- 
tion of adjoining Tarim and Qaidam basins, NW China. Terra Nova, 2003, 13: 86-91

53 Guo Z J, Lu J M, Zhang Z C. Cenozoic exhumation and thrusting in the northern Qilian Shan, northeastern margin of the Tibetan Plateau: Constraints from sedimentological and apatite fission-track Data. Acta Geol Sin, 2009, 83: 801-840

54 Schärer U, Zhang L S, Tapponnier P. Duration of strike-slip movements in large shear zones: The Red River belt, China. Earth Planet Sci Lett, 1994, 126: 379-397

55 Dupont-Nivet G, Krijgsman W, Langereis C G, et al. Tibetan plateau aridification linked to global cooling at the Eocene-Oligocene transition. Nature, 2007, 445: 635-638

56 Hodges K V. Tectonics of the Himalaya and southern Tibet from two perspectives. Geol Soc Am Bull, 2000, 112: 324-350

57 Yin A, Harrison T M. Geologic evolution of the Himalayan-Tibetan orogen. Annu Rev Earth Planet Sci, 2000, 28: 211-280

58 Hurtado J M, Hodges K V, Whipple K X. Neotectonics of the Takkhola Graben and implications for recent activity on the South Tibetan Fault System in the central Nepalese Himalaya. Geol Soc Am Bull, 2001, 113: 222-240

59 Searle M P, Godin L. The south Tibetan detachment and the Manaslu leucogranite: A structural reinterpretation and restoration of the Annapurna-Manaslu Himalaya, Nepal. J Geol, 2003, 111: 505-523

60 Yin A. Cenozoic tectonic evolution of the Himalayan orogen as constrained by along-strike variation of structural geometry, exhumation history, and foreland sedimentation. Earth Sci Rev, 2006, 76: 1-131

Open Access This article is distributed under the terms of the Creative Commons Attribution License which permits any use, distribution, and reproduction in any medium, provided the original author(s) and source are credited. 